$$
\begin{gathered}
\text { University of Szeged } \\
\text { Faculty of Pharmacy } \\
\text { Department of Pharmaceutical Technology } \\
\text { Head: Prof. Dr. Habil. Piroska Szabó-Révész Ph.D., D.Sc. }
\end{gathered}
$$

Ph.D. Thesis

\title{
Development and characterization of modified release oral preparations containing riboflavin
}

\author{
by \\ Gyula Buchholcz \\ Pharmacist
}

Supervisor:

Prof. Dr. Habil. Klára Pintye-Hódi Ph.D., D.Sc.

Szeged

2015 


\section{PUBLICATIONS:}

I. Buchholcz Gyula, Erős István, Hódi Klára:

Gyógyszer-filmbevonó anyagok és eljárások Fókuszban az Eudragit@.

Gyógyszerészet, 48, 651-658 (2004)

II. Buchholcz Gyula, Hódi Klára:

Amit a vitaminokról röviden tudni kell - A sokoldalú B2-vitaminról bővebben. Gyógyszerészet, 55, 538-542 (2011)

III. Gyula Buchholcz, András Kelemen, Klára Pintye-Hódi:

Modified-release capsules containing sodium riboflavin 5'-phosphate.

Drug Development and Industrial Pharmacy, 2014, 40, 1632-1636

IV. Gyula Buchholcz, András Kelemen, Tamás Sovány, Klára Pintye-Hódi:

Matrix tablets based on a carrageenan with the modified-release of sodium riboflavin 5'-phosphate.

Pharmaceutical Development and Technology, 2014, DOI: $10.3109 / 10837450.2014 .910810 \quad$ IF: 1.202

V. András Kelemen, Gyula Buchholcz, Tamás Sovány, Klára Pintye-Hódi:

Evaluation of the swelling behaviour of iota-carrageenan in monolithic matrix tablets.

Journal of Pharmaceutical and Biomedical Analysis, 2015, 112, 85-88

IF: 2.979

\section{PRESENTATIONS:}

I. Gy. Buchholcz, I. Erős, J. Pintye, K. Pintye-Hódi: Preparation of sustained-release capsule containing sodium riboflavin phosphate pellets,

EAHP Congress Sevilla (2004)

II. Buchholcz Gyula, Erős István, Hódi Klára: B2-vitamin tartalmú kapszula előállítása, MGYT KGYSZ Kongresszus Debrecen (2004)

III. Gy. Buchholcz, I. Erős, K. Pintye-Hódi: Influence of the thickness of coating films on the dissolution of sodium riboflavin phosphate,

CESPT Congress Siófok (2005)

IV. Buchholcz Gyula, Kelemen András, Sovány Tamás, Hódi Klára: Módosított hatóanyagleadású B2-vitamin tartalmú monolitikus mátrix tabletta előállítása, Congressus Pharmaceuticus Hungaricus XV. Budapest (2014) 


\section{CONTENTS}

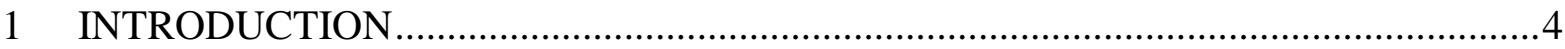

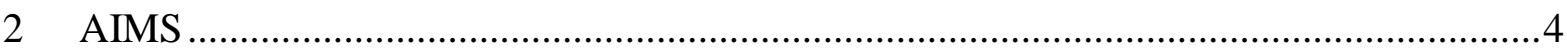

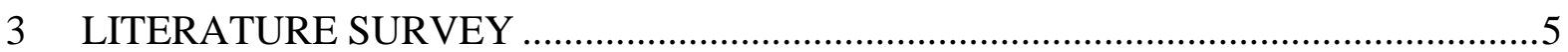

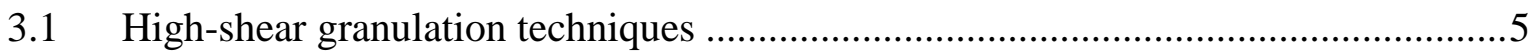

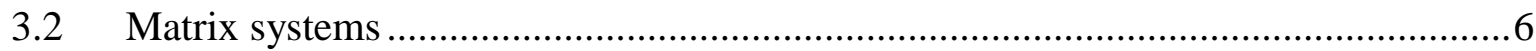

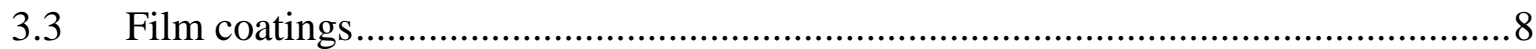

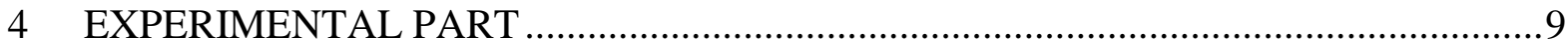

4.1 SAMPLES I. Production of modified release capsules .......................................

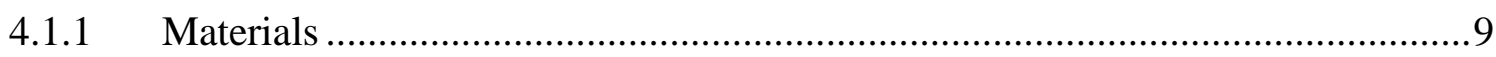

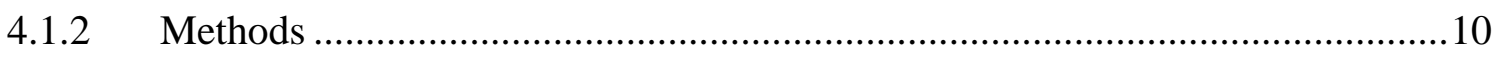

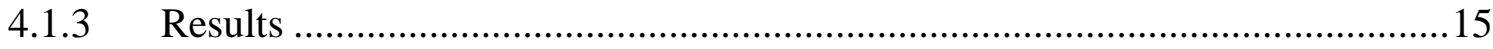

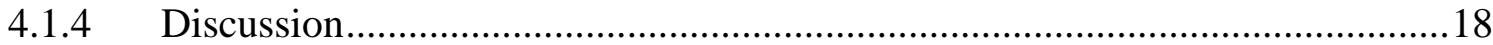

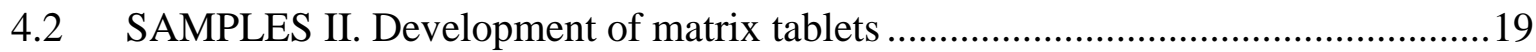

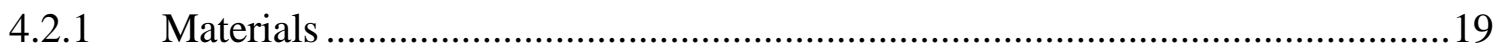

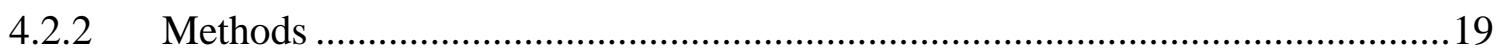

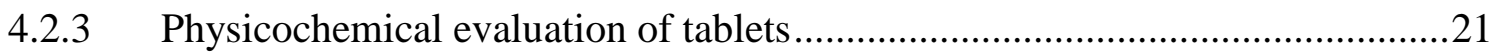

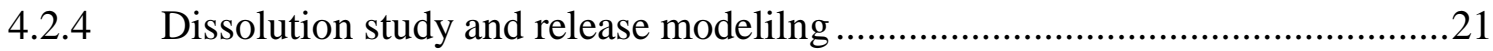

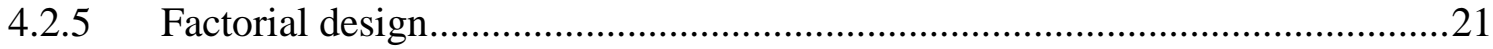

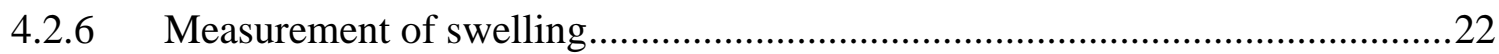

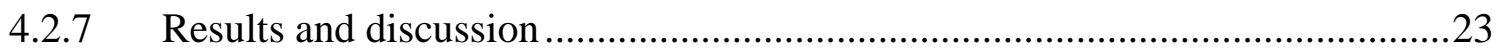

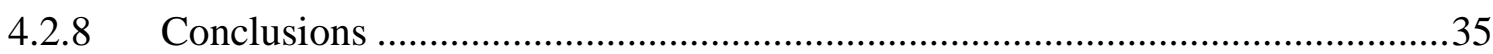

5 FINAL CONCLUSIONS, NOVELTY, PRACTICAL USEFULNESS .........................36

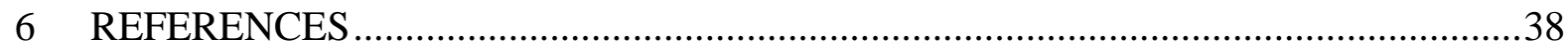

\section{ACKNOWLEDGEMENTS}

APPENDIX 


\section{INTRODUCTION}

The vitamins essential for living organisms are normally consumed in small amounts with the food. These organic materials facilitate the biochemical reactions that produce, among others, skin, bone and muscle. Once growth and development are completed, the vitamins remain essential nutrients for the healthy maintenance of the cells, tissues and organs; they also ensure the efficient use of the chemical energy provided by the food and promote the processing of the proteins, carbohydrates and fats required for respiration [1].

Riboflavin (Fig. 1.), a sparingly water-soluble vitamin that is a component of the coenzymes flavin adenine dinucleotide (FAD) and flavin mononucleotide (FMN) is important in the utilization of food and the interconversion of energy.

$$
\begin{aligned}
\text { riboflavin }+A T P & \longrightarrow F M N+A D P \\
F M N+A T P & \longrightarrow F A D+P P
\end{aligned}
$$

Riboflavin has no overt pharmacological effects following its oral or parenteral administration. FMN and FAD, the physiologically active forms of riboflavin, serve a vital metabolic role as coenzymes for a wide variety of respiratory flavoproteins, some of which contain metals (e.g. xanthine oxidase) [2]. A deficiency of vitamin $\mathrm{B}_{2}$ is associated with eye and skin disorders.

There are a number of preparations containing riboflavin on the market, e.g. effervescent tablets and instant granules. Modern therapy additionally requires a modified release dosage form since the riboflavin-containing drugs have poor oral bioavailability due to the narrow absorption window in the gastrointestinal tract.

\section{AIMS}

Riboflavin is readily absorbed from the upper gastrointestinal tract by a specific transport mechanism involving phosphorylation of the vitamin to FMN. Here and in other tissues, riboflavin is converted to FMN by flavokinase, in a reaction that is sensitive to the 
thyroid hormone status [2]. Altough riboflavin is widely distributed in the body tissues, little is stored in the body [3].<smiles>Cc1cc2nc3c(=O)[nH]c(=O)nc-3n(C[C@H](O)[C@H](O)[C@H](O)CO)c2cc1C</smiles>

Figure 1. Riboflavin

Riboflavin may be absorbed in the duodenum and jejunum, but the extent of absorption at these sites is limited because the passage through this region is rapid. The bioavailability of riboflavin may be increased by the administration of a gastroretentive or modified release dosage form [4]. Techniques are available that permit the production of drugs with poor colonic absorption, but better absorption properties in the upper parts of the gastrontestinal tract. These dosage forms may provide excellent results with drugs that act locally in the upper regions of the gastrontestinal tracts.

The main goal of the work reported in the thesis was to examine the possibility of improving the bioavailability of narrow absorption window drugs through the use of film-coated capsules and modified release monolithic matrix tablets. The secondary goal was to identify relationships between the rate of release of the drug from capsules or tablets in vitro and the corresponding pharmacokinetic profile.

\section{LITERATURE SURVEY}

\subsection{High-shear granulation techniques}

Granulation is a size-enlargement process that decreases the specific surface area via reduction of the adhesion between the powder particles. Wet and dry granulation are distinguished [5-9]. The most frequently used apparatus includes low-/and high-shear 
granulators, e.g. fluid bed granulators and spray driers [10]. Granulation has two goals: manufacture of the final dosage form, or the production of intermediates for tablet compression [11].

High-shear wet granulation consists in the agglomeration of different particles by liquid addition and strong mixing [11-14]. The typical formulation comprises the following phases: homogenization of dry powders by use of an impeller; liquid addition; wet massing with the liquid feeding system switched off, and finally granule drying [15]. Excipients are regularly used, e.g. binders, diluents, disintegrants, stabilizing agents and pigments. Most high-shear granulators are fitted with small chopper blades turning at high speeds that break down large agglomerates.

The advantages of high-shear wet granulation advantages are: a shorter process time, more dense and less friable granules, and less granulation liquid consumption as compared to with other granulators [10].

\subsection{Matrix systems}

Oral sustained-release technologies may be classified according to different criteria, including the type of release (e.g. delayed, slow, prolonged, pulsed, repeat-action, etc.), the release machanism (e.g. diffusion, dissolution, etc.) or the type of the technological system. They are classified on the basis of their rate-controlling mechanism, e.g. diffusion, erosion/chemical reactions, swelling and osmosis. Diffusion-controlled release systems are categorized in two types: reservoir systems and monolithic matrix systems. A reservoir system utilizes a membrane that serves as the main diffusion barrier, while in a monolithic matrix system the active pharmaceutical ingredient (API) is incorporated in a polymer [16-19]. In this case the drug dissolution is controlled by diffusion or erosion. The polymer used may be a swellable (Fig. 2.) or a non-swellable matrix or an erodable matrix. Natural, hydrophilic matrices are used worldwide for oral administration, because they are simple and relatively inexpensive modified release formulations. 

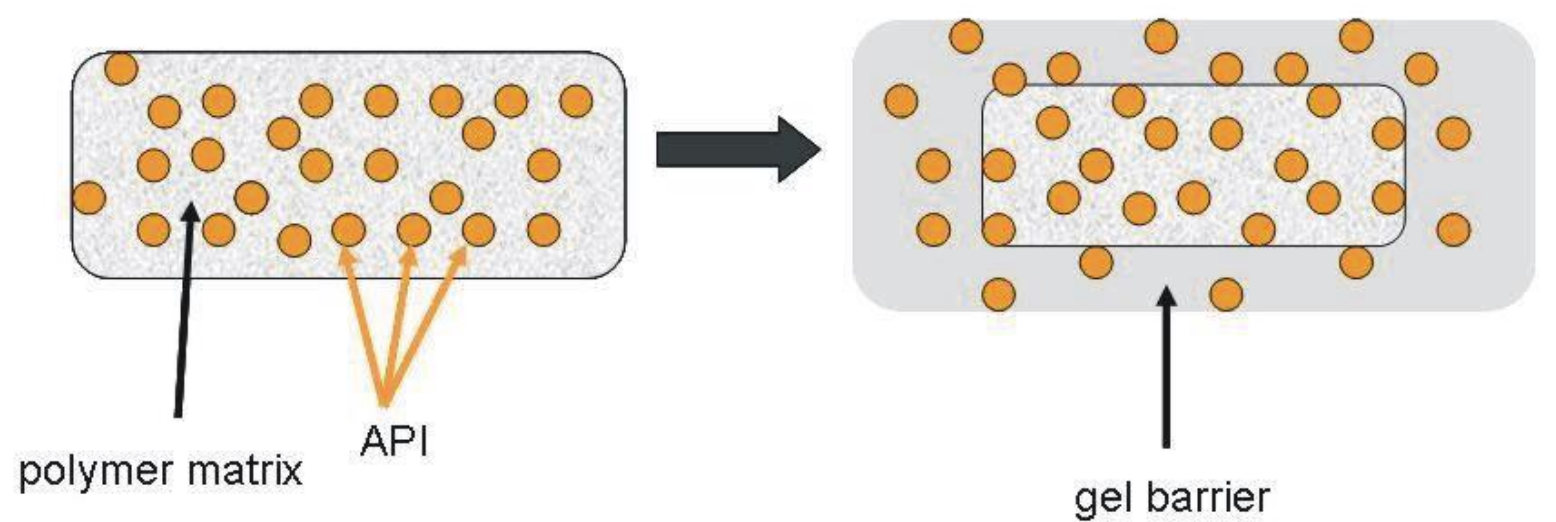

Figure 2. Swellable matrix tablet

The most common naturally-occurring polymers are cellulose, carrageenan, alginate and xanthan [20-22].

Carrageenans are linear polysaccharides, built up from repeating galactose and 3,6anhydroglactose units, either sulfated or non-sulfated.
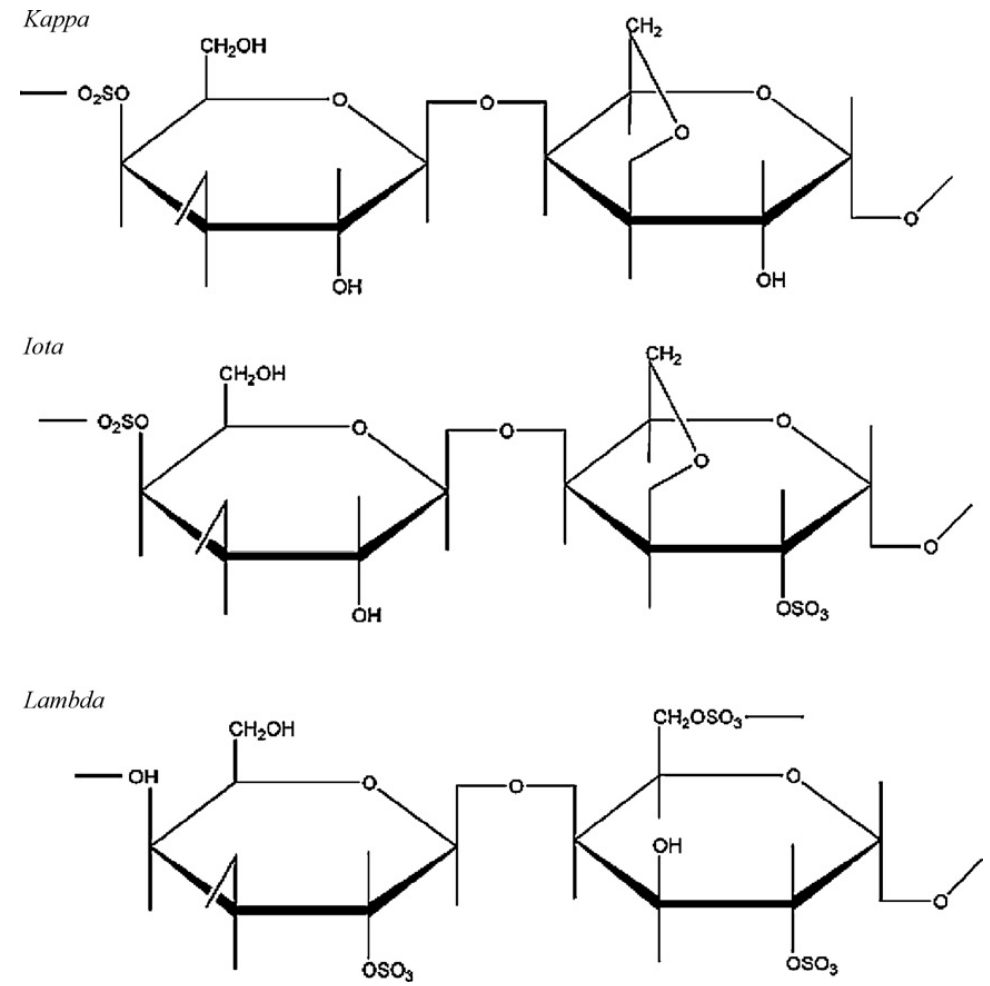

Figure 3. Major carrageenan fractions 
The units are joined by alternating alpha 1-3 and beta 1-4 glycosidic linkages. There are three main carrageenan forms: lambda, kappa and iota (Fig. 3.), which differ in their chemical structures and properties, and therefore in their uses. Lambda-carrageenan does not form gels, but yields high-viscosity solutions. Iota-carrageenan forms elastic gels with calcium salts; these gels are clear with no bleeding of liquid (no syneresis) and are freeze/thaw-stable. Kappacarrageenan furnishes strong, rigid gels with potassium salts, and brittle gels with calcium salts. These gels are slightly opaque, but become clear on the addition of sugar and exhibit some syneresis [23-26]. Carrageenans are often used in the pharmaceutical industry to optimize prolonged-release formulations [27, 28].

With the above-mentioned swellable matrices, the rate of disintegration determines the drug release profile, and the swelling force is proportional to the rate of disintegration. Study of the swelling behaviour of swellable matrices therefore plays an important role in the prediction of the drug release profile [22, 29-33].

\subsection{Film coatings}

The oral route is most often used for the administration of drugs. Coated tablets, gelatin capsules, granulates and pellets are the major oral dosage forms. Coating is an extremely important technique in the formulation of pharmaceutical dosage forms and is a very common process in drug manufacturing [34-37]. Coating processes are carried out to provide physical and chemical protection for the drugs in the dosage forms, and modification of the drug-release characteristics.

The modern coating techniques began in the 19th century with sugar coating, which was principally used to provide a pleasant taste and an attractive appearance for tablets. However, the processing time required for the sugar coating is too long, the operator must be highly skilled and standardization of the procedure is difficult.

Film coating has a number of advantages, including time-, material- and work-saving, while the film thickness is only $20-100 \mu \mathrm{m}$, and the weight gain is $\leq 150 \mathrm{mg}$ [38]. In general, the film coating is applied by using organic solvents or aqueous solutions. Since organic solvents tend to be flammable and toxic the applications of organic solvent-based film coating are limited and pharmaceutical companies prefer the use of water as solvent [39]. Film-coating formulations usually contain the following components: 
- polymer,

- plasticizer,

- pigment,

- vehicle.

The film formers in use today are polymers: polymethacrylates, cellulose-based polymers, polyvinyl derivativ and other copolymers [40,41]. The polymer layer is soluble (pH-dependent or $\mathrm{pH}$-independent dissolution) or becomes permeable. The research work described in the present thesis involved an investigation of the Eudragit NE 30D, a polymethacrylate-based (ethyl acrylate-methyl methacrylate) water-insoluble, swelling copolymer applied to achieve sustained-release film coating [42-44].

A coating process consists in simultaneous spraying, mixing and a drying process. The coating process is commonly influenced by the process parameters (e.g. the pan speed, the air pressure, the spraying rate, the inlet and outlet air temperatures, the number of spray nozzles, the atomization pressure, the coating time, etc.).

The permeability of the membrane is determined by the thickness of the coating, which depends on the above-mentioned parameters and the nature of the polymer layer.

\section{EXPERIMENTAL PART}

\subsection{SAMPLES I. Production of modified release capsules}

\subsubsection{Materials}

Sodium riboflavin 5'-phosphate (BASF AG, Ludwigshafen, Germany) was used as active agent (Fig 4.) $1.0 \mathrm{~g}$ of sodium riboflavin 5'-phosphate is equivalent to about $0.73 \mathrm{~g}$ of riboflavin. This salt dissolves in water more easily than riboflavin itself, but it has the same absorption and excretion characteristics as those of riboflavin [45]. 


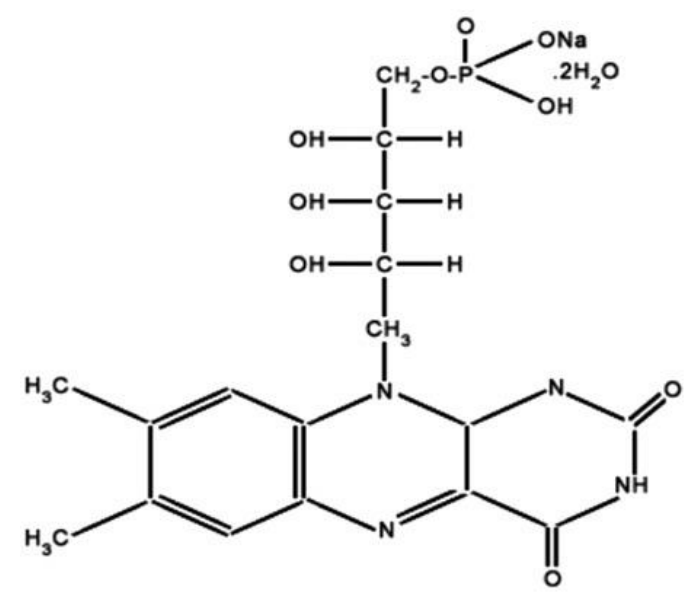

Figure 4. Sodium riboflavin 5'-phosphate

Cellet 300 (Microcrystalline Cellulose Spheres, Shin-Etsu Chemical Co., Ltd., Tokyo, Japan; a gift from Harke Pharma, Mühlheim, Germany) served as core material, and Eudragit NE 30D (ethyl acrylate methyl-methacrylate copolymer, Evonik GmbH, Darmstadt, Germany) as coating material. The coating dispersion contained Dimeticon E (an antifoaming agent, type E1049, a gift from EGIS Pharmaceuticals PLC, Budapest, Hungary) and hydrophilic colloidal silicon dioxide (Aerosil 200 (Ph.Eur) and talc (PhEur) as anti-sticking agents. Ethanol $96 \%$ and purified water were used as solvents.

\subsubsection{Methods}

\subsubsection{Core layering}

The core pellets (Cellet 300) were loaded with a $10 \%$ aqueous solution of sodium riboflavin 5'-phosphate by a layering technique in a coating pan (Dragex-1, Jorgen Jorgensen Maskinfabrik A/S, Copenhagen, Denmark). The rate of rotation speed of the coating pan was $23 \mathrm{rpm}$. The nozzle size of the Walther spray gun was $0.8 \mathrm{~mm}$. The atomizing spraying pressure was 0.6 bar and the spraying rate was $5 \mathrm{ml} / \mathrm{min}$. The drying temperature was adjusted to $30-35^{\circ} \mathrm{C}$.

The Cellet layered with sodium riboflavin 5'-phosphate was filled into hard HPMC capsules (Capsugel Ltd, Antwerpen Belgium). A Zuma 150/A4 semiautomatic capsule filling machine (Zuma Srl, Milan, Italy) was used. 


\subsubsection{Capsule coating}

The composition of the coating dispersion was as follows:

Eudragit NE 30D 75.24 g, Dimeticon E $5.8 \mathrm{~g}$, Aerosil $2000.44 \mathrm{~g}$, ethanol 96\% $18.68 \mathrm{~g}$, talc $3.34 \mathrm{~g}$, and purified water $86.74 \mathrm{~g}$. The nozzle size and type were the same as in the layering process. The atomizing spraying pressure was 0.8 bar and the spraying rate was 5 $\mathrm{ml} / \mathrm{min}$. The coating pan was rotated at $23 \mathrm{rpm}$, and the drying temperature was $25-30{ }^{\circ} \mathrm{C}$.

The coating dispersion was used in various quantities: $50.0 \mathrm{~g}$ (capsule A: dry material content: $7.5 \mathrm{~g}$ ), $100.0 \mathrm{~g}$ (capsule B: dry material content: $15.0 \mathrm{~g}$ ) or $250.0 \mathrm{~g}$ (capsule C: dry material content: $32.0 \mathrm{~g})$.

\subsubsection{Tests on coated capsules \\ Coating film thickness}

A Mitutoyo screw micrometer was used to determine the thicknesses of the coating film on the cap and the corpus of the capsules. The diameter of the capsule was measured with $0.001 \mathrm{~mm}$ accuracy before and after coating.

\section{Dissolution tests}

The rate of dissolution of the drug was determined by the Münzel half-change method [46]. This allows the use of artificial gastric fluid and artificial intestinal fluid of varying $\mathrm{pH}$ values in the range 1.2-7.5 (Table 1).

Table 1. Variation of $\mathrm{pH}$ during the half-change dissolution process

\begin{tabular}{|c|c|c|}
\hline Interval (h) & Gastric fluid/Intestinal fluid & $\mathrm{pH}$ \\
\hline $0-1$ & $100 / 0$ & 1.2 \\
$1-2$ & $50 / 50$ & 1.91 \\
$2-3$ & $25 / 75$ & 6.24 \\
$3-4$ & $12.5 / 87.5$ & 6.92 \\
$4-5$ & $6.25 / 93.75$ & 7.22 \\
$5-6$ & $3 / 97$ & 7.39 \\
$6-7$ & $1 / 99$ & 7.48 \\
$7-8$ & $0 / 100$ & 7.50 \\
\hline
\end{tabular}


Dissolution tests were carried out in an Erweka DT 700 dissolution apparatus (Erweka $\mathrm{GmbH}$, Heusenstamm, Germany), using a paddle method. The volume of the dissolution medium was $900 \mathrm{ml}$. The test started with gastric fluid (without enzymes), and after each hour a sample was taken for concentration determination, and half of the bulk solution was then replaced with fresh intestinal fluid. The dissolution temperature was maintained at $37 \pm 0.5{ }^{\circ} \mathrm{C}$ and the rotation rate was set at $100 \mathrm{rpm}$. Samples $(5 \mathrm{ml})$ were collected automatically from the dissolution medium at 1, 2, 3, 4, 5, 6 and $7 \mathrm{~h}$. Three replicates were tested for each capsule formulation batch. Absorbance was measured spectrophotometrically (Unicam He $\lambda$ ios Alpha, Spectronic Unicam, Cambridge, UK) at $\lambda_{\max }=266 \mathrm{~nm}$. At any time $(t)$, the total quantity of drug released from the capsule is defined as given in Table 2.

Table 2. Amount of drug released as a function of time

\begin{tabular}{|c|c|c|}
\hline$t$ & Concentration of solution & Total drug amount released $\left(A_{t}\right)$ \\
$(\mathrm{h})$ & $(\%)$ & $(\%)$ \\
\hline 1 & $Q_{1}$ & $A_{1}$ \\
2 & $\frac{Q_{1}}{2}+Q_{3}$ & $A_{2}$ \\
3 & $\frac{Q_{1}}{2}+\frac{Q_{2}}{2}+Q_{3}$ & $A_{3}$ \\
\hline$n$ & $\frac{Q_{1}}{2}+\frac{Q_{2}}{2} \ldots . \frac{Q_{l n-1 /}}{2}+Q_{n}$ & $A_{n}$ \\
\hline
\end{tabular}

\subsubsection{Statistical evaluation}

Model-independent evaluation

The dissolution efficiency $(D E)$ can be calculated via the following expression:

$$
D E=\frac{\int_{0}^{t} m(t) d t}{m_{100} t} \cdot 100
$$

where $m(t)$ is the amount of API dissolved at time $t$, and $m_{100}$ is the amount of API dissolved at $100 \%$ dissolution. 
Depending on the shape of the dissolution curve, various mathematical models can be used to describe the dissolution process (first-order, Higuchi, Hixson-Crowell, Hopfenberg, Korsmeyer-Peppas, Rosin-Rammler-Sperling-Benett-Weillbull (RRSBW) (modified Weibull), etc.) [47]. The RRSBW model is generally utilized to describe the dissolution profile in the event of a sigmoid shape. Another model that can be used in this case is the ChapmanRichards model [48].

The coefficient of determination $\left(R^{2}\right)$ is frequently used as criterion to assess the best model equation. In this study we applied RRSBW distribution and the Chapman-Richards growth function to fit the dissolution profiles.

\section{RRSBW model}

RRSBW distribution is commonly used as the mathematical model in dissolution studies $[49,50]$. This distribution is generally described by the following empirical equation:

$$
M(t)=M_{\infty}\left(1-e^{-\frac{(t-T)^{\beta}}{a}}\right)
$$

where $M(t)$ is the amount of API dissolved as a function of time $t, M_{\infty}$ is the maximum amount of API dissolved, $T$ is the lag time, $a$ is a scale parameter that describes the time dependence, and $\beta$ describes the shape of the curve.

For $\beta=1$, the shape of the curve corresponds exactly to the shape of an exponential profile with constant $k=1 / a$. This implies first-order kinetics in the dissolution process:

$$
M(t)=M_{\infty}\left(1-e^{-k(t-T)}\right)
$$

For $\beta=0$, the equation is

$$
M(t)=M_{\infty}\left(1-e^{-\frac{1}{a}}\right)
$$

For $\beta<1$, relatively rapid dissolution is observed at the beginning of the process, followed by a slower process. 
For $(t-T)^{\beta}=a$, the equation is

$$
\frac{M(t)}{M_{\infty}}=1-e^{-\frac{a}{a}}=1-e^{-1}=0.632
$$

where $a=t_{63.2 \%}$ is a characteristic dissolution time.

\section{Chapman-Richards model}

The Chapman-Richards method involves a 3-parameter sigmoid growth function based on the Bernoulli differential equation. This differential equation is used to describe the growth of an arbitrary quantity as the difference between its constructive growth and destructive growth [51]:

$$
\frac{d M}{d t}=\alpha M^{\beta}-\gamma M
$$

where $M$ is the quantity, $\alpha M^{\beta}$ is the constructive part and $\gamma M$ is the destructive part. The general solution of this differential equation is the 3-parameter Chapman-Richards function:

$$
M(t)=M_{\infty}\left(1-e^{-k t}\right)^{\beta}
$$

where $M_{\infty}, k$ and $\beta$ are the regression parameters to be estimated.

The dissolution profiles were fitted with Eq. 7, where $M(t)$ is the amount of API dissolved as a function of time, $M_{\infty}$ is the total amount of the API, $k$ is the dissolution rate and $\beta$ describes the shape of the curve, which refers to the lag time of the dissolution.

As in the RRSBW model, $\beta=1$ implies first-order kinetics. 


\subsubsection{Results}

\section{Coating film thickness}

The film thickness the and uniformity of the coating play an important role in the dissolution. It was therefore important to determine the film thickness.

The measurement data are summarized in Table 3.

Table 3. Film thickness on the capsule surface

\begin{tabular}{|l|l|l|}
\hline Capsule & \multicolumn{2}{|l|}{ Film thickness $(\mu \mathrm{m})$} \\
& Cup & \multicolumn{2}{|c|}{ Corpus } \\
\hline A & $161 \pm 12$ & $182 \pm 5$ \\
\hline B & $200 \pm 20$ & $240 \pm 36$ \\
\hline C & $227 \pm 26$ & $269 \pm 36$ \\
\hline
\end{tabular}

The film thickness is seen to increase with increase of the coating dispersion, but the data also reveal a difference in the thickness of the films on the cup and the corpus of the coated capsules. The latter is primarily due to the shape of the capsules: there is always some difference $(\sim 30-40 \mu \mathrm{m})$ in the diameters of the cup and the corpus. The difference in the film thickness is not more than in the case of the uncoated capsule. This suggests that the coated dispersion spreads on the surface of the capsules during coating, and forms a uniform coating film on the surface of the capsules.

\section{Dissolution tests}

In the first step, we tested the rate of dissolution rate of riboflavin from uncoated capsules in artificial gastric fluid for comparison with the coated capsules. The results showed that the total riboflavin (100\%) dissolved during $60 \mathrm{~min}$.

The dissolution tests (by half change method) on the coated capsules clearly demonstrated the influence of the film thickness on the release of the drug (Fig. 5.). 


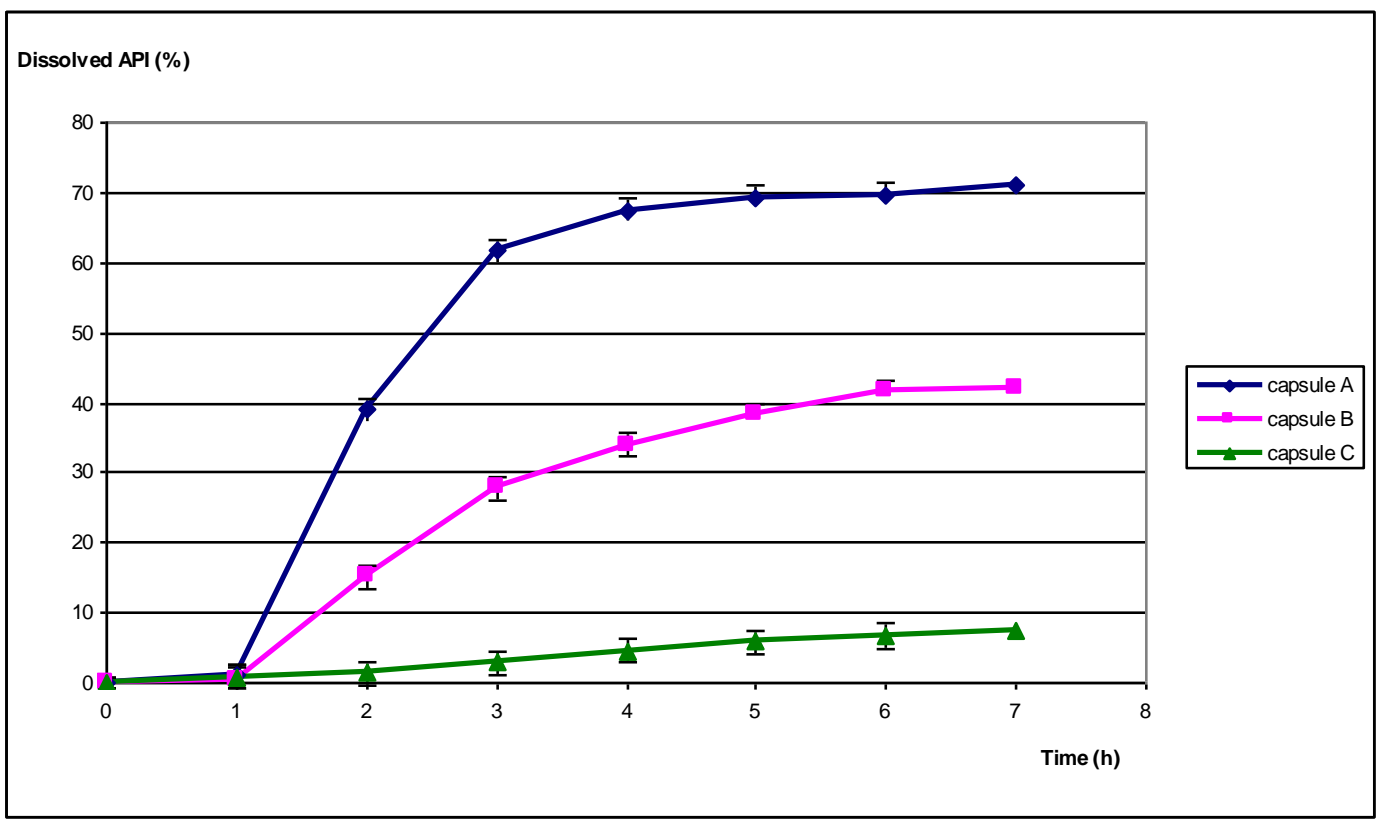

Figure 5. Dissolution of riboflavin from coated capsules

Table 4. Parameters of dissolution curves

\begin{tabular}{|l|l|l|l|l|l|l|l|}
\hline Capsule & \multicolumn{3}{|c|}{ RRSBW model } & \multicolumn{3}{c|}{ Chapman-Richards model } \\
\hline & $\beta$ & $a$ & $R^{2}$ & $M_{\infty}$ & $\beta$ & $k$ & $R^{2}$ \\
\hline A & 1.3602 & 1.3186 & 0.9171 & 69.6771 & 16.8461 & 1.66817 & 0.9991 \\
\hline B & 1.6813 & 2.4113 & 0.9228 & 42.2965 & 5.2131 & 0.8363 & 0.9970 \\
\hline
\end{tabular}

The dissolution profile exhibited a sigmoid shape in the cases of capsules A and B. These are typical dissolution curves of a delayed-release dosage form. However, capsule A is to be preferred in view of the present aim, because much of the API $(\sim 70 \%)$ was released at $\mathrm{pH} \approx 7$.

The independent statistical evaluation of the results demonstrated that the efficiency of the mechanism of dissolution $(D E)$ was highest in the case of capsule A. 
Table 5. Results of the model-independent evaluations

\begin{tabular}{|c|c|}
\hline Capsule & $D E(\%)$ \\
\hline $\mathrm{A}$ & 54.14 \\
\hline $\mathrm{B}$ & 28.47 \\
\hline $\mathrm{C}$ & 4.2 \\
\hline
\end{tabular}

Various mathematical models were tested to describe the dissolution process (see above), and the RRSBW and Chapman-Richards model proved best. The results with these are presented in Table 4.

The $R^{2}$ data revealed that the dissolution curves for capsules $\mathrm{A}$ and $\mathrm{B}$ are well described by the Chapman-Richards equation.

The curve for capsule $\mathrm{C}$ was fitted by linear fitting $\left(R^{2}=0.9949\right)$, but the corresponding $D E$ was not high enough, and hence it was not considered further.

The data in Table 5 demonstrate that the $D E$ of capsule A was best, but the amount of API dissolved was only $\approx 70 \%$. It is also evident that the coating film thickness influences the degree of dissolution of the drug. The question arises as to how the bioavailability of riboflavin from the capsules can be enhanced. What is the best film thickness for total release to be attained in the small intestine during $2-5 \mathrm{~h}$ ?

To answer this question, we created a theoretical model based on the Chapman-Richards method with respect to the fitting results. In this model, 95-100\% of the API is released between 2 and $5 \mathrm{~h}$. On the basis of this theoretical model and the measurement results, we calculated the optimum thickness of the coating via the following formula:

$$
d_{o p t}=d_{A}-\left(d_{B}-d_{A}\right) \frac{s_{m}-s_{A}}{s_{A}-s_{B}}
$$

where $d_{o p t}$ is the optimum thickness, $d_{A}$, and $d_{B}$ are the thicknesses of the films on capsule A and capsule B, $s_{m}$ is the slope of the model dissolution profile, and $s_{A}$ and $s_{B}$ are the slopes of the dissolution curves for capsule A and capsule B, respectively. 
In this case, the predicted optimum film thickness on the corpus which ensures the required dissolution is $112.1 \mu \mathrm{m}$ (Fig. 6.).

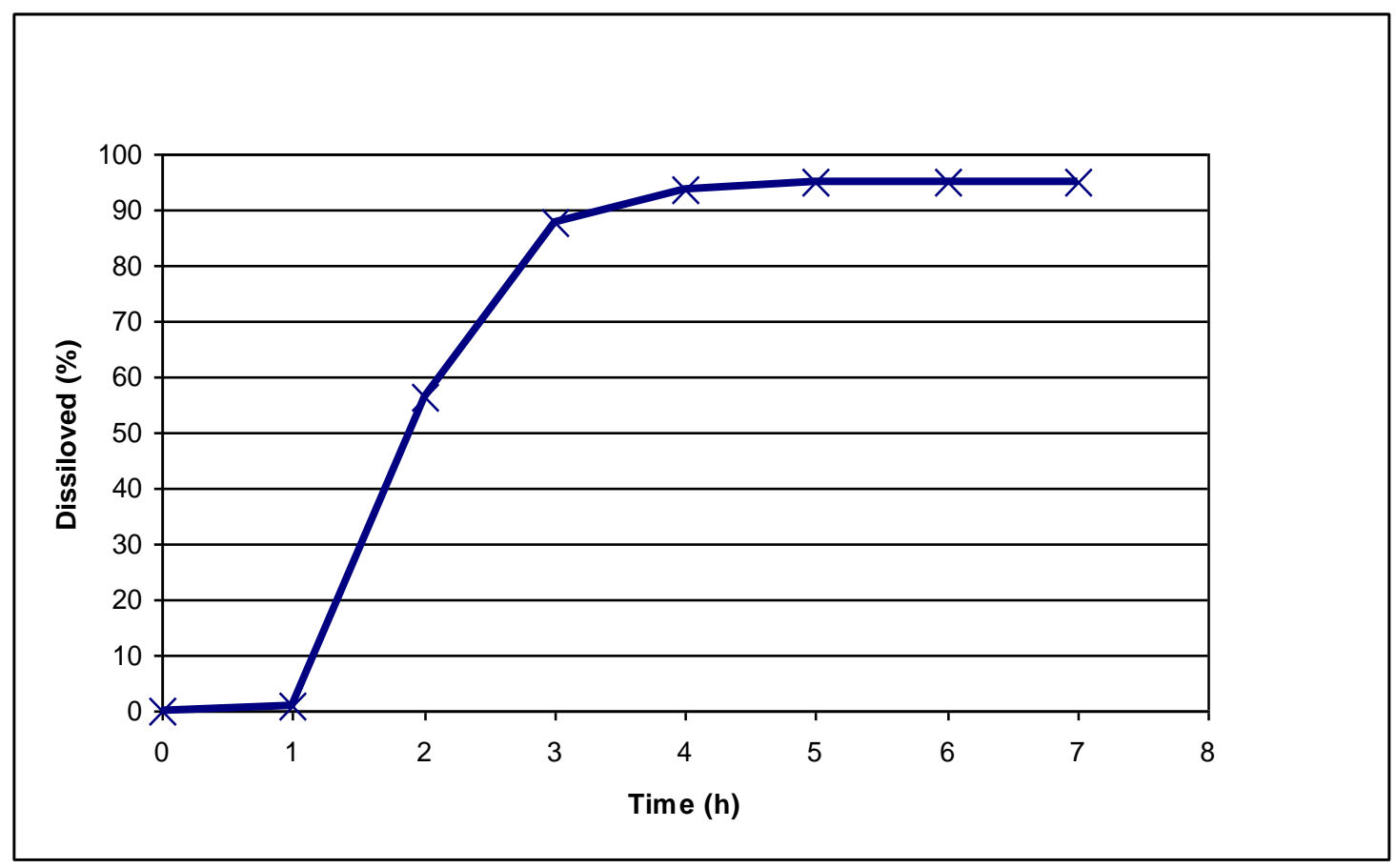

Figure 6. Predicted dissolution profile at a film thickness of $112.1 \mu \mathrm{m}$ on the corpus

\subsubsection{Discussion}

In this work, a new solid dosage form was developed through the layering of aqueous sodium riboflavin 5'-phosphate solution on the surface of microcrystalline pellets (Cellet 300) as core material, which were then filled into capsules. The hard capsules were coated with Eudragit NE coating material in different thicknesses. Naturally, further pharmacokinetic testing is necessary to confirm the appropriate bioavailability. Statistical analysis of the dissolution curves indicated that the best products were described by the Chapman-Richards equation. The results were utilized to create a theoretical model suitable for prediction of the optimum. 


\subsection{SAMPLES II. Development of matrix tablets}

\subsubsection{Materials}

Sodium riboflavin 5'-phosphate (BASF AG, Ludwigshafen, Germany) was used as API, Gelcarin GP 379 NF (iota-carrageenan) (FMC BioPolymer, Philadelphia, USA) as swellable matrix material, microcrystalline cellulose (MCC) (Vivapur® 102) (Rettenmaier\&Söhne GmbH, Rosenberg, Germany) as non-swellable matrix-forming wicking material, and lactose (PhEur) as a filling excipient.

\subsubsection{Methods}

\subsubsection{Preparation of granules}

The homogenization and wetting of the powder mixture were performed in a high-shear mixer (ProCepT 4M8 granulator, ProCepT nv, Zelzate, Belgium; Fig 7.).

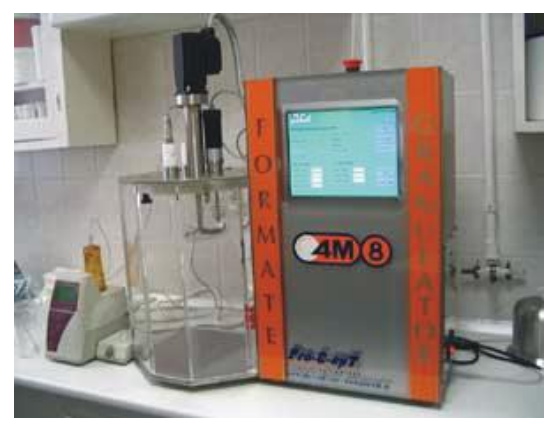

Figure 7. ProCepT 4M8 granulator

The ratios of the powder components were varied according to a $3^{2}$ factorial design, as in Table 6.

Table 6. Compositions of powder mixtures

\begin{tabular}{|c|c|c|c|c|}
\hline $\begin{array}{l}\text { Gran } \\
\text { code }\end{array}$ & $\begin{array}{c}\text { Iota- } \\
\text { carrageenan } \\
(\%)\end{array}$ & $\begin{array}{c}\text { MCC } \\
(\%)\end{array}$ & $\begin{array}{c}\alpha \text {-lactose } \\
\text { monohydrate } \\
(\%)\end{array}$ & $\begin{array}{c}\mathrm{MCC} /(\mathrm{MCC} \\
\text { +lactose) } \\
\text { ratio }(\%)\end{array}$ \\
\hline Gran1 & 30 & 45 & 25 & 64.5 \\
\hline$\overline{\text { Gran2 }}$ & 30 & 55 & 15 & 78.6 \\
\hline$\overline{\text { Gran3 } 3}$ & 30 & 35 & 35 & 50 \\
\hline
\end{tabular}


Homogenization parameters:

Impeller speed: $1000 \mathrm{rpm}$

Chopper speed: $0 \mathrm{rpm}$

Homogenization time: 5 min

$\underline{\text { Kneading parameters: }}$

Impeller speed: $1000 \mathrm{rpm}$

Chopper speed: $5000 \mathrm{rpm}$

Dosing speed: $10 \mathrm{ml} / \mathrm{min}$

Amount of API solution: $120 \mathrm{ml}$ (in three portions)

The wet granules obtained were sieved through a sieve with $1.2 \mathrm{~mm}$ wire distance and were dried at $22 \pm 2{ }^{\circ} \mathrm{C} / 65 \pm 5 \%$ relative humidity.

\subsubsection{Tableting}

The dry granules were mixed with $2 \%$ of magnesium stearate in a Turbula mixer at $50 \mathrm{rpm}$, for $2 \mathrm{~min}$. The resulting granules were compressed into tablets at 5, 10 or $15 \mathrm{kN}$ with a Korsch EK0 instrumented eccentric tablet machine (Emil Korsch Maschinenfabrik, Berlin, Germany). The compression tools were slightly concave punches $9 \mathrm{~mm}$ in diameter, the pressure force was calibrated with a Wazau HM-HN-30kN-D cell (Kaliber Ltd., Budapest, Hungary), and the compression was carried out electrically at $36 \mathrm{rpm}$, at $24{ }^{\circ} \mathrm{C}$ air temperature and $45 \%$ relative air humidity. The average mass of the tablets was $0.200 \pm 0.01$ g. 500 tablets were compressed at each compression force for each sample (when possible). Lots with relative standard deviations not exceeding $5 \%$ were accepted.

Model tablets for swelling investigations were also prepared with the above-mentioned Korsch EK0 eccentric tableting machine, but these tablets contained only the matrix former polymer (iota-carrageenan). The applied compression forces were again 5, 10 and $15 \mathrm{kN}$. 


\subsubsection{Physicochemical evaluation of tablets}

The average and individual masses were measured with an analytical balance (Sartorius AG, Göttingen, Germany). The breaking strength (Heberlein, Flisa, Le Locle, Switzerland), friability (Erweka GmbH, Heusenstamm, Germany) and geometry of the tablets, including thickness and diameter (Mitutoyo screw micrometer, accuracy $0.001 \mathrm{~mm}$, Mitutoyo Co. Kawasaki, Japan), were determined. 20 tablets were tested in every case.

\subsubsection{Dissolution study and release modelling}

Dissolution tests were carried out in an Erweka DT 700 dissolution apparatus (Erweka GmbH, Heusenstamm, Germany), using the paddle method (Dissolution test for solid dosage forms Apparatus 2 (paddle method) [52].

The dissolution was tested in gastric fluid $(\mathrm{pH}=1.2)$ and phosphate buffer $(\mathrm{pH}=4.5)$. At the beginning of the process, the dissolution medium was $900 \mathrm{ml}$ of gastric juice (adjusted according to the $\mathrm{Ph}$. Eur.). The dissolution temperature was maintained at $37 \pm 0.5^{\circ} \mathrm{C}$ and the rotation rate was set at $100 \mathrm{rpm}$. Samples $(2 \mathrm{ml})$ were automatically collected from the dissolution medium at 30, 60, 90 and $120 \mathrm{~min}$. The dissolution medium was then changed to phosphate buffer under the former conditions and samples were again taken at 30,60, 90, 120, 150 and $180 \mathrm{~min}$. The total potential dissolution time was therefore $300 \mathrm{~min}(5 \mathrm{~h})$. Three replicates were tested for each tablet formulation batch. Absorbance was measured spectrophotometrically (Unicam He $\lambda$ ios Alpha, Spectronic Unicam, Cambridge, UK) at $\lambda_{\max }$ $=266 \mathrm{~nm}$.

The dissolution data were calculated by statistical analysis and the release profiles were fitted with different models.

\subsubsection{Factorial design}

To reveal the relationships between composition, process parameters and tablet properties, the experiments were performed according to a $3^{2}$ full factorial design (Statistica for Windows). The independent factors were the $\mathrm{MCC} /(\mathrm{MCC}+$ lactose $)$ ratio in the composition and the applied compression force. The optimization parameters were the amount of API dissolved after $5 \mathrm{~h}$, and the friability and breaking hardness of the tablets. 


\subsubsection{Measurement of swelling}

Swelling force was measured with equipment developed in our laboratory (see below). Tablets were prepared at different pressures (see below) and their swelling was tested in hydrochloric acid of $\mathrm{pH} 1.2$ and in phosphate buffer of $\mathrm{pH} 4.5$. The temperature applied was $37^{\circ} \mathrm{C}$ and the duration of measurements was 30 min. Five parallels were measured.

The measurement was performed with a Sartorius microbalance with electronic compensation, built into the equipment with the DAQ hardware. The built-in DAQ unit is based on a PIC16F871-I/P microcontroller. The Sartorius balance and the temperature sensor were connected to ADC channel 0 and channel 1, respectively. The equipment was linked to a PC via an RS232 cable as shown in Fig. 8.

The tablet-holder was a copper cylinder $10 \mathrm{~mm}$ in diameter with slits in the side, into which a copper punch with the same diameter was fitted. The tablet was placed in the holder, the equipment heated the aqueous solution to the desired temperature, the liquid was injected and measurements were started.

The aqueous solution penetrated into the tablet through the slits. The force that built up inside the comprimate as it absorbed the liquid was transmitted vertically and was detected by the built-in Sartorius balance. During the measurement, the embedded software used the timer interrupt for the DAQ from the ADC channels [53].

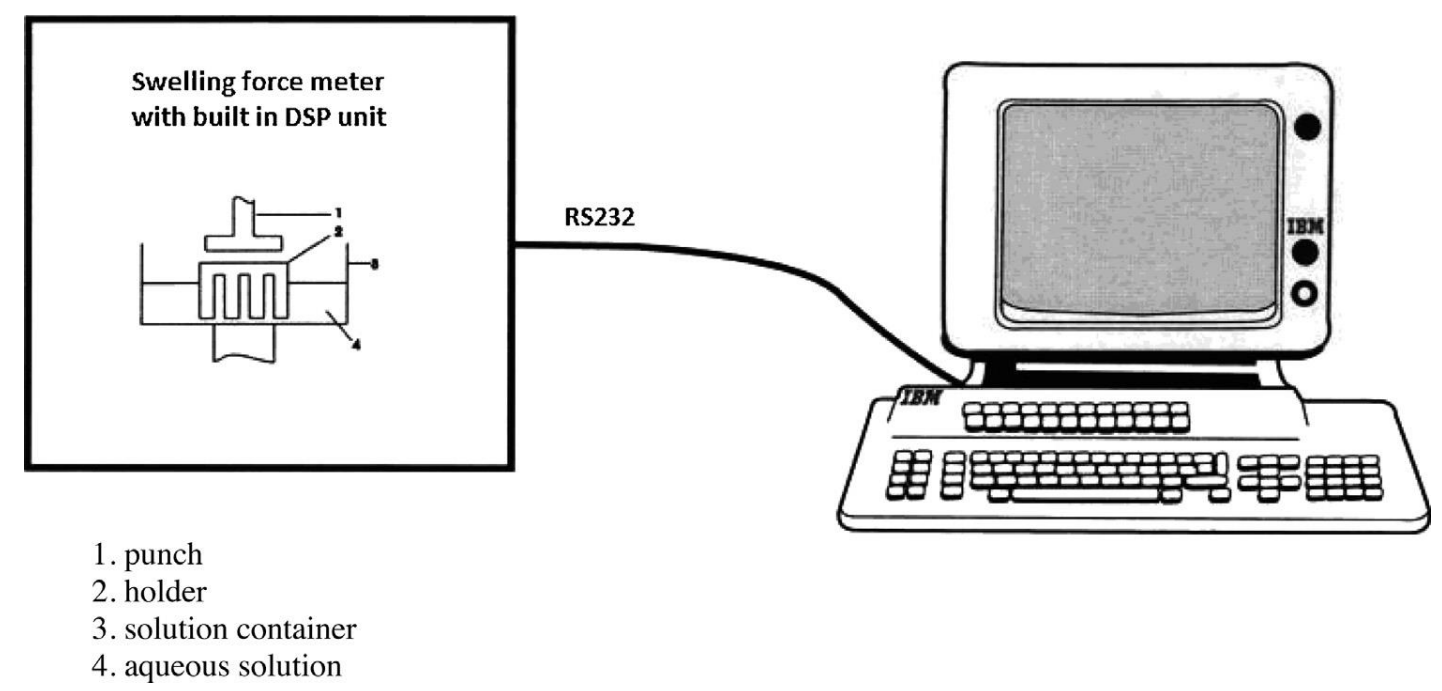

Figure 8. Experimental set-up of the swelling force meter [54] 
Software was developed for data acquisition, evaluation and demonstration of the swelling process. The monitor displayed the swelling force vs. time curve with the important parameters (the swelling force and the characteristic swelling time $\left(t_{63.2 \%}\right)$ ). An Analysis menu facilitated fitting of the swelling curve.

\subsubsection{Results and discussion}

\subsubsection{Granulation}

In the high-shear granulator used, it was possible not only to set the important working parameters, but also to follow the process and measure the changes in temperature and impeller torque. The latter parameter is very informative because it shows the optimum end- point of the suitable consistency of the wet mass. Many publications have dealt with the importance of end-point detection and the influence on this of the composition of the granules $[15,55,56]$. Our experiments revealed (Fig. 9.) that the $\mathrm{MCC} /(\mathrm{MCC}+$ lactose) ratio (in the range used) did not significantly influence the temperature increase (about $20^{\circ} \mathrm{C}$ ). Likewise, there were not great differences in impeller torque, but there was a tendency for the end-point to increase to a small degree with increase of the lactose content. The impeller torque was $23 \%$ at the $\mathrm{MCC} /(\mathrm{MCC}+$ lactose) ratio of $78.6 \%$ (Gran2); $26 \%$ at the $\mathrm{MCC} /(\mathrm{MCC}+$ lactose) ratio of $64.5 \%$ (Granl), and $31 \%$ at the $\mathrm{MCC} /(\mathrm{MCC}+$ lactose) ratio of $50 \%$ (Gran3).

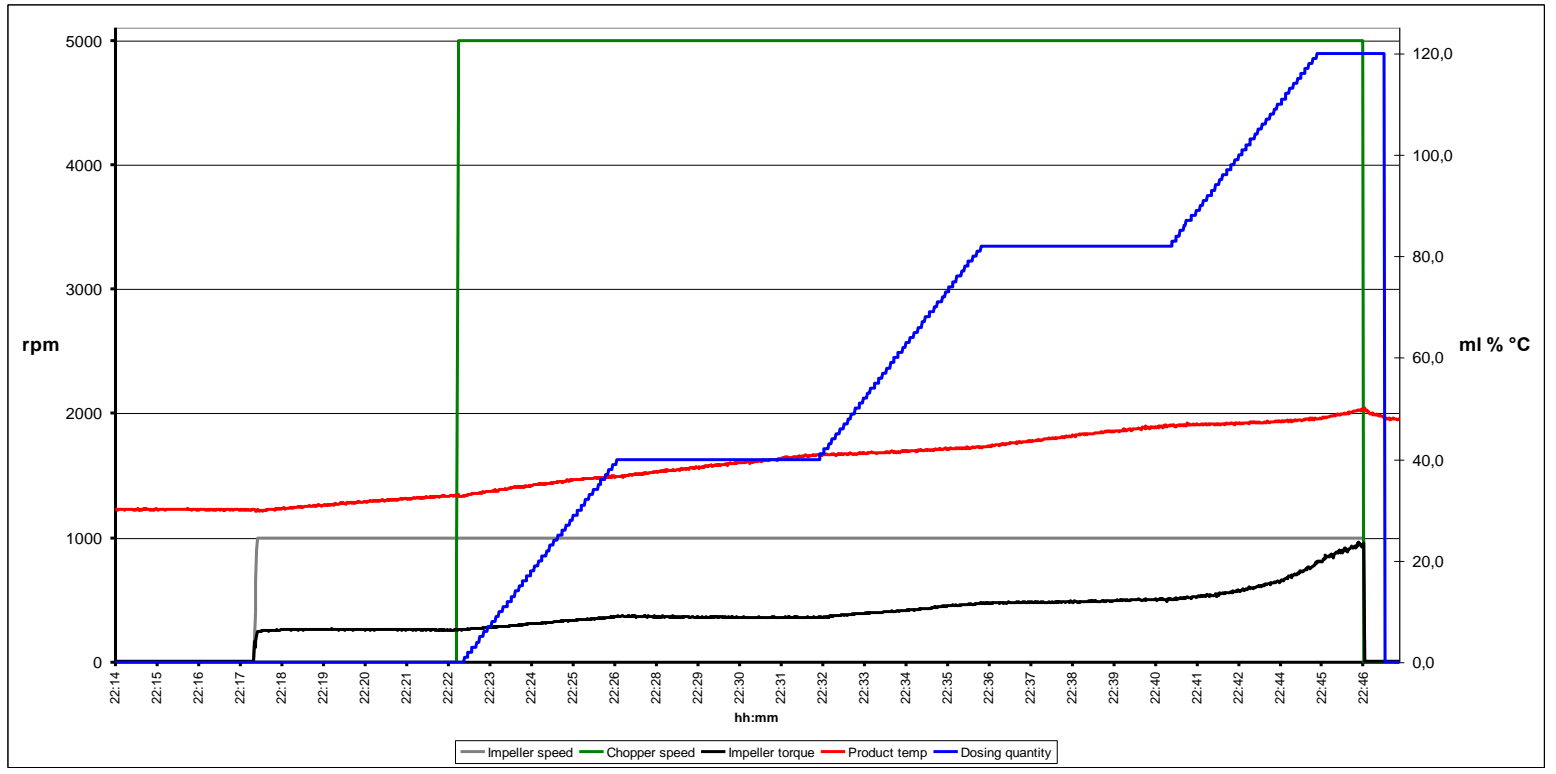

Figure 9. Granulation process of Gran2 sample 


\subsubsection{Tableting}

The redispersed dry granules (moisture content: $5.00 \pm 0.5 \%$ ) were mixed with magnesium stearate and compressed. The physicochemical parameters of the tablets are presented in Table 7.

Table 7. Physicochemical parameters of tablets

\begin{tabular}{|l|c|c|c|c|c|c|}
\hline Samples & $\begin{array}{c}\text { Compression } \\
\text { force } \\
(\mathbf{k N})\end{array}$ & Mass & $\begin{array}{c}\text { Breaking } \\
\text { hardness } \\
(\mathbf{g})\end{array}$ & $\begin{array}{c}\text { Friability } \\
\mathbf{( N )}\end{array}$ & Diameter & Height \\
\hline Ribotabl & 5 & 0.192 & 48.35 & 0.50 & $\mathbf{( m m )}$ & $\mathbf{( m m )}$ \\
(ratio 64.5) & 10 & 0.211 & 50.90 & 0.48 & 8.994 & 2.597 \\
& 15 & 0.204 & 54.80 & 0.43 & 8.993 & 2.426 \\
\hline Ribotab2 & 5 & 0.195 & 37.50 & 1.54 & 8.911 & 2.409 \\
(ratio 78.6) & 10 & 0.197 & 37.10 & 1.21 & 8.932 & 2.445 \\
& 15 & 0.195 & 37.60 & 1.07 & 8.940 & 2.421 \\
\hline Ribotab3 & 5 & 0.200 & 38.63 & 0.33 & 9.058 & 2.508 \\
(ratio 50) & 10 & 0.210 & 57.95 & 0.36 & 9.036 & 2.507 \\
& 15 & 0.200 & 59.40 & 0.14 & 9.033 & 2.383 \\
\hline
\end{tabular}

It can be seen from the data that the accuracy of the mass was good; this means that the flowability of the granules and the filling of the die cavity were uniform. The mechanical parameters (breaking hardness and friability) demonstrate the differences between the samples.

The results were evaluated according to the factorial design, the factors are described in section 4.2.5. The design matrix and the corresponding results are to be seen in Table 8 . 
Table 8. Design of experiments

\begin{tabular}{|c|c|c|c|c|}
\hline $\begin{array}{c}\text { MCC/(MCC + lactose) } \\
\text { ratio (\%) }\end{array}$ & $\begin{array}{c}\text { Compression } \\
\text { force }(\mathrm{kN})\end{array}$ & $\begin{array}{c}\text { Breaking } \\
\text { hardness }(\mathrm{N})\end{array}$ & Friability (\%) & $\begin{array}{c}\text { Amount of drug } \\
\text { dissolved after } \\
5 \mathrm{~h}(\%)\end{array}$ \\
\hline 50.0 & 5.0 & 38.63 & 0.33 & 100 \\
50.0 & 10.0 & 57.95 & 0.36 & 100 \\
50.0 & 15.0 & 59.40 & 0.13 & 82 \\
\hline 64.5 & 5.0 & 48.35 & 0.50 & 65 \\
64.5 & 10.0 & 50.90 & 0.48 & 63 \\
64.5 & 15.0 & 54.80 & 0.42 & 51 \\
\hline 78.6 & 5.0 & 37.50 & 1.54 & 71 \\
78.6 & 10.0 & 37.10 & 1.22 & 84 \\
\hline 78.6 & 15.0 & 37.60 & 1.07 & 82 \\
\hline
\end{tabular}

The mechanical properties of the tablets seemed more robust than the dissolution data. (The dissolution curves are displayed below.) Neither the composition nor the compression force influenced this parameter significantly (Eq. 9); only the linear component of the MCC/(MCC + lactose) ratio proved to be of minor significance when the non-linear interactions were not taken into account, but this resulted in a decreased goodness of fit $\left(R^{2}=0.8266\right.$ vs. 0.9393$)$.

$y=46.91-7.30 x_{1}+3.33 x_{1}^{2}+4.55 x_{2}+1.30 x_{2}^{2}-5.17 x_{1} x_{2}-2.35 x_{1} x_{2}^{2}-1.23 x_{1}^{2} x_{2}^{2}$

The decreasing value of the breaking hardness (Fig. 10.) and the corresponding increase in friability (Fig. 11.) may be due to the resistance of the granules against compression at high MCC content. 


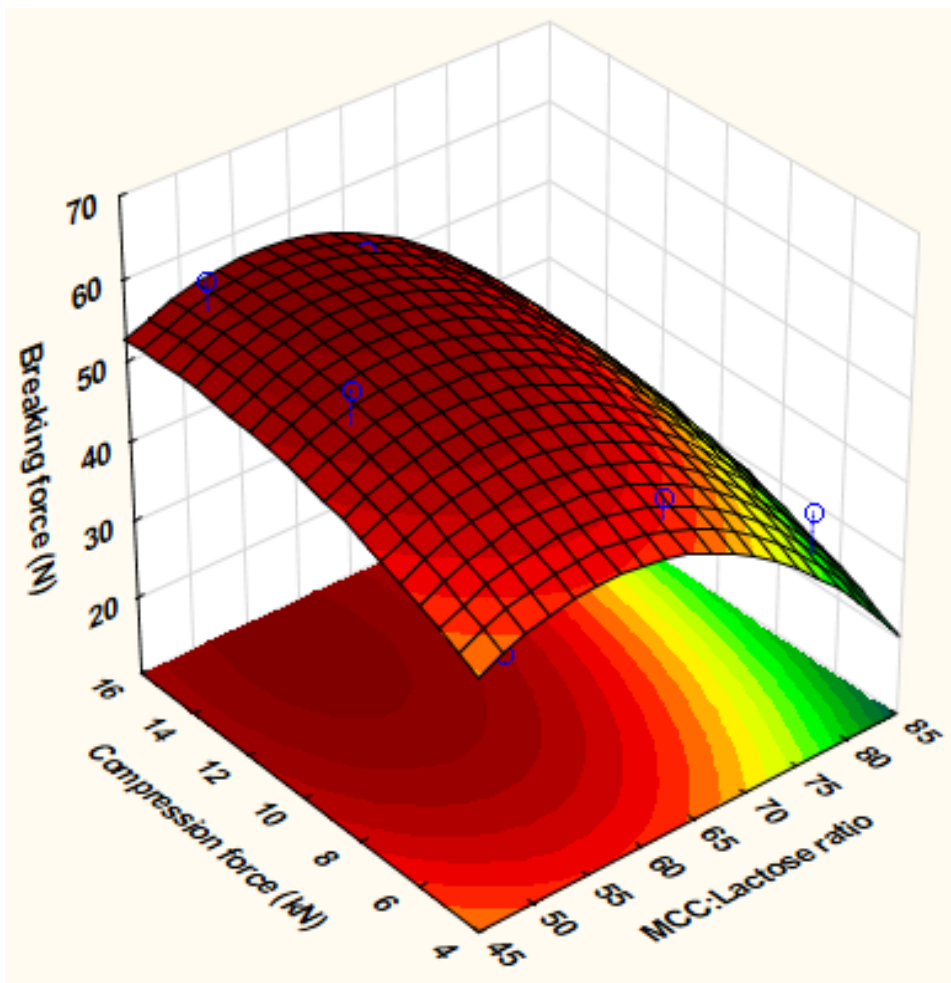

Figure 10. Response surface for the breaking hardness of the tablets

The results suggest that MCC loses its deformability during granulation, which results in a decreased binding capacity and a decreased mechanical strength of the tablets. Nevertheless, the mechanical problems are connected more with the abrasion than with the breaking of the tablets, as indicated by the higher sensitivity of the friability to the composition of the tablets (Eq. 10).

$$
y=0.67+\mathbf{0 . 5 0} x_{1}-\mathbf{0 . 1 5} \boldsymbol{x}_{1}^{2}-0.12 x_{2}+0.008 \mathrm{x}_{2}^{2}-0.07 x_{1} x_{2}
$$

The significant factors are indicated with bold-faced type.

The $\mathrm{MCC} /(\mathrm{MCC}+$ lactose $)$ ratio significantly influenced the friability both linearly and nonlinearly. Unfortunately, the consideration of the quadratic interactions resulted in overdetermination of the model, and these effects were therefore neglected during the analysis.

The data in Table 6 demonstrate that in the case of Ribotabl [MCC/(MCC + lactose) ratio $64.5 \%$ ] the compression force did not influence the hardness of the tablets or the geometrical 
parameters. The Ribotab2 tablets exhibited a very a small breaking hardness, which was independent of the compression force. These tablets contained the smallest proportion of lactose (Gran2). With the MCC particles, the carrageenan formed a monolithic matrix with elastic behavior, which was not disturbed by the lactose particles. This was explained by the friability values, which revealed a higher elastic recovery in the tablets after compression. The compensatory behaviour of the MCC particles was not sufficient. Ribotab3 was prepared with much more lactose (Gran 1$)$. In this case the tablets produced at $5 \mathrm{kN}$ exhibited a small breaking hardness, which increased with increasing compression force, especially at $10 \mathrm{kN}$. Further increase of the compression force caused only a very small increase in hardness. The friability values indicated stronger binding in the texture of the tablets in the elastic recovery phase.

The results of the statistical evaluation revealed that even when the non-significant interactions between the factors were taken into account, the goodness of the fitted model increased significantly. In the case of the API dissolution, the adjusted $R^{2}$ was 0.7712 with no interactions, 0.9490 with linear interactions, and 0.9972 with the application of the quadratic interactions too. It can be concluded that the API dissolution is mostly affected by the $\mathrm{MCC} /(\mathrm{MCC}+$ lactose $)$ ratio, and a strong non-linear relation can be observed between these two parameters (Fig. 12.). The compression force applied had a non-significant effect on this parameter, but it strongly interacted with the compositional parameter (Eq. 11).

$y=77.56-7.50 x_{1}-13.42 x_{1}^{2}-3.50 x_{2}+3.58 x_{2}^{2}+7.25 x_{1} x_{2}-2.63 x_{1}^{2} x_{2}-0.81 x_{1}^{2} x_{2}^{2}$

The significant values are highlighted in bold-type format. The highest values of dissolution were observed at high lactose content, which can be explained by the increasing porosity of the matrix due to the dissolution of the lactose. Nevertheless, the higher dissolution rate at low lactose proportions may be due to the weak effect of the MCC which results in a higher rate of water penetration into the matrix and forced dissolution of the drug from the internal pores of the system. 


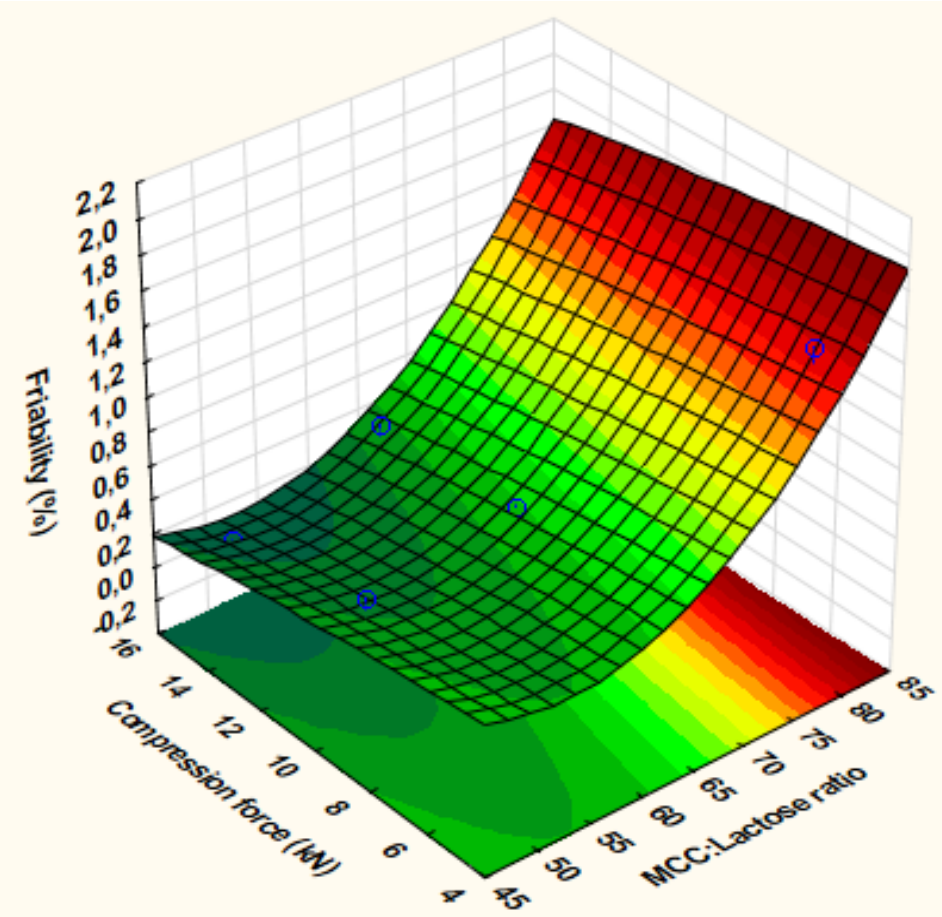

Figure 11. Response surface of the friability

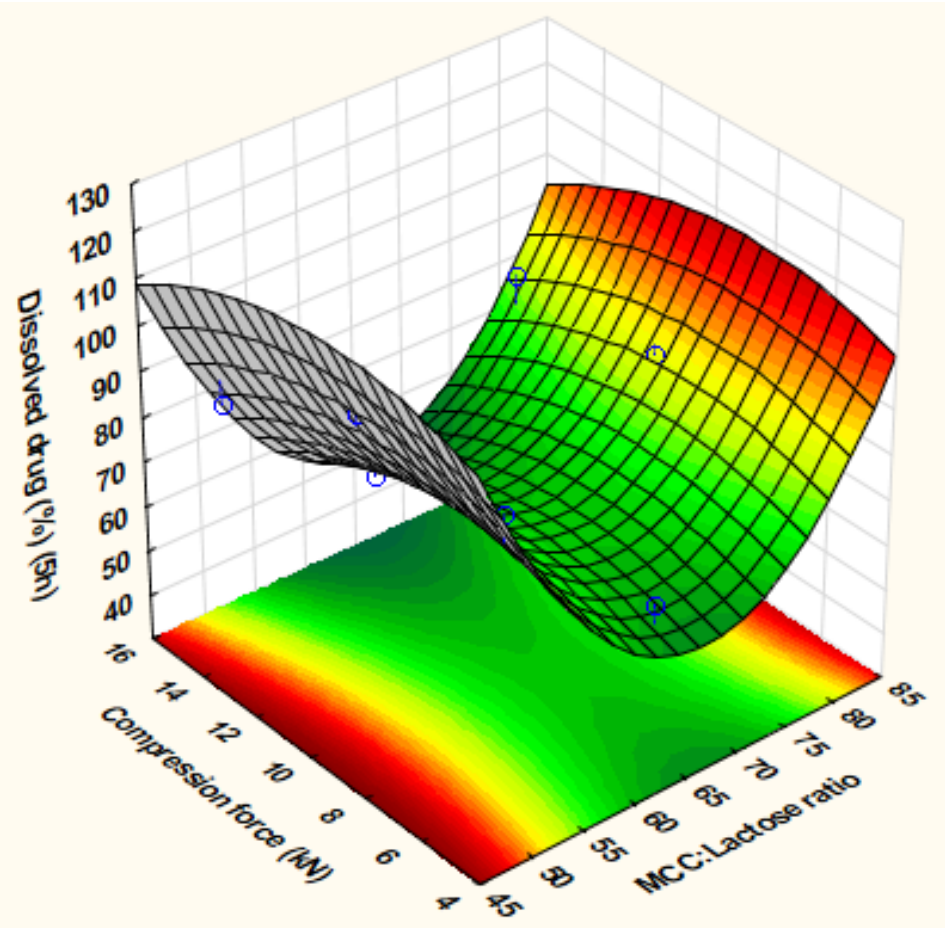

Figure 12. Response surface of drug dissolution 
The dissolution curves of the tablets are displayed in Figs 13-15. It can be observed that the curves frequently display a break-point.

In the case of Fig. 13. (Ribotab1), a break-point is not seen in the curve at $5 \mathrm{kN}$, but with increase of the compression force the break-point becomes clearer. This is in accordance with the hardness values of these tablets. In the tablets compressed at $5 \mathrm{kN}$, the binding can break more easily in the gastric juice; the texture of the tablets is more porous. The swelling of the macromolecular particles come off streamline; and at the change of the dissolution medium, the gastric juice can wash out readily from the matrix. In the case of a compact matrix system, it is more difficult for the phosphate buffer to pass into the interior of the tablet.

Ribotab2 (Fig. 14.) contained the lowest proportion of lactose. At $5 \mathrm{kN}$, where the matrix formed was more porous, the macromolecular particles could swell readily in the gastric juice and the API could dissolve. However the swelling later resulted in a gel form and, after the change of the dissolution medium, the phosphate buffer could not pass easily into the swollen particles; at first, a saturated section occurred in the dissolution profile. The degree of swelling of the carrageenan particles hindered the complete release of the API. In this case, the $10 \mathrm{kN}$ compression force was best for the preparation of the tablets, because the texture of the tablets and the swellability were in equilibration. The release profile showed a uniform increase up to $80 \%$. The tablets compressed at $15 \mathrm{kN}$ also showed that the particles of the macromolecules did not swell to such a high degree and the dissolution rate was practically the same as for the former tablets.

Figure 15 best demonstrated the role of lactose during the dissolution process. The Ribotab3 tablets contained lactose in highest proportion in the matrix system. The particles of lactose could disperse to a high degree between the macromolecular particles. It can be seen from Table 7 that the mechanical hardness of these tablets was the weakest; it is well known that lactose is a brittle material and is not able to form hard binding during loading [57]. The dissolution process of the tablets compressed at $5 \mathrm{kN}$ is not depicted here as the deviation was too high. Only the dissolution profiles, of the 10 and $15 \mathrm{kN}$ tablets are illustrated. Lactose, a well-soluble excipient, which can be incorporated between the macromolecular particles, promotes the release of the API. The total amount of the API was dissolved from the tablets compressed.at $10 \mathrm{kN}$. Further increase of the compression force would not have been advantageous, because the more compact texture prevented the total dissolution of the API during $5 \mathrm{~h}$. 
The dissolution data were subjected to statistical analysis. The Korsmeyer-Peppas model (Eq. 12) proved to characterize the total dissolution profile best:

$$
\frac{m_{t}}{m_{\infty}}=k t^{n}
$$

where $m_{t} / m_{\infty}$ is the fraction of the API released at time $t, k$ is the rate constant and $n$ is the release exponent.

The $R^{2}$ values revealed rather strong correlations (Table 9.), but because of the break-points in the dissolution profiles, we took the dissolution data in two groups and fitted all the sections according to the Korsmeyer-Peppas and the linear model. The first section was the period 0$120 \mathrm{~min}$ and the other 150-300 min. The results are presented in Tables 10 and 11.

It can be seen from the data in Table 10 that the correlation is strong, especially in the first section of the dissolution profile.

The fitting with the linear model was also examined:

$$
\frac{m_{t}}{m_{\infty}}=a t+b
$$

where $m_{t} / m_{\infty}$ is the fraction of the API released at time $t, a$ is the slope and $b$ is the intersection.

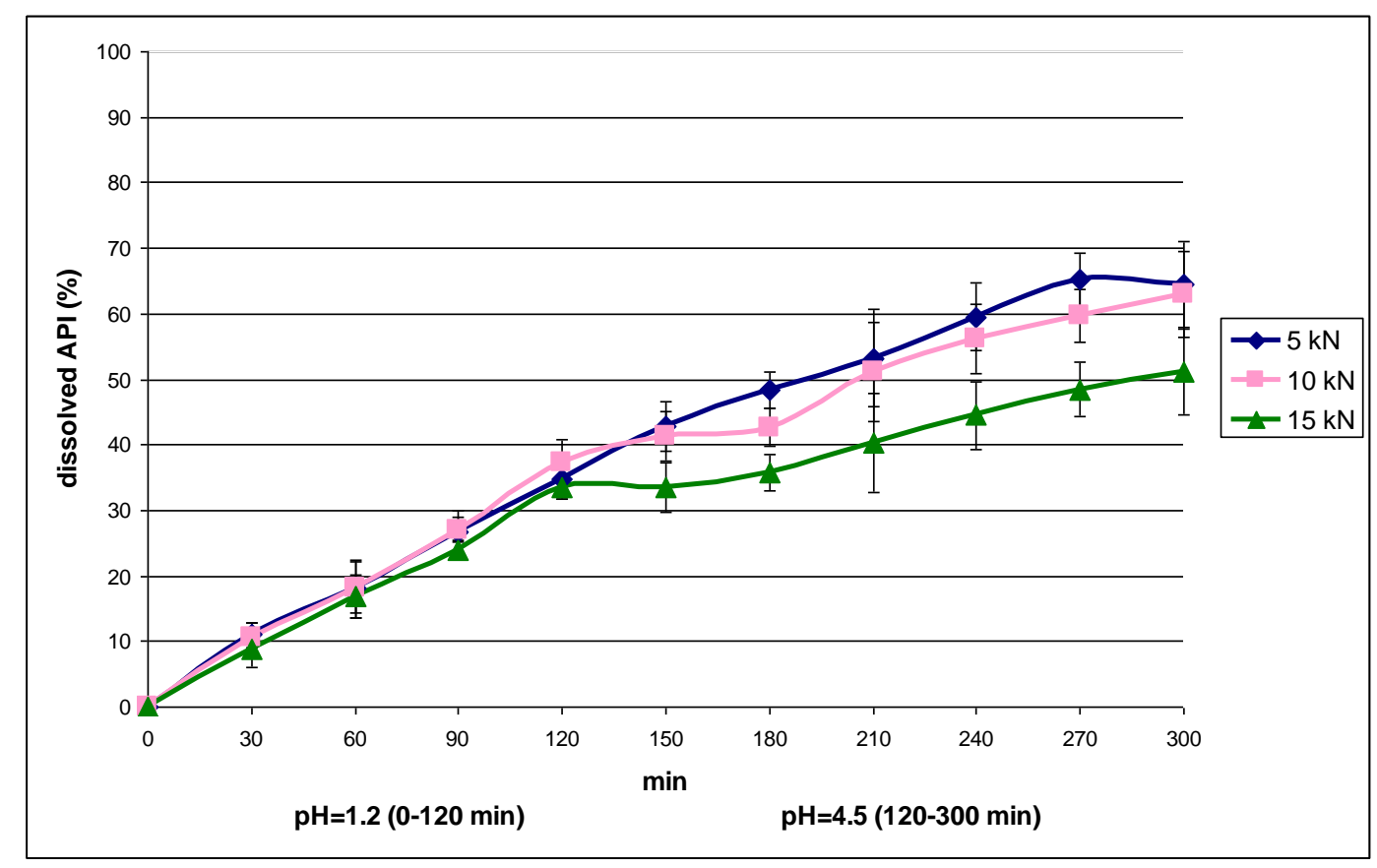

Figure 13. Dissolution curves for Ribotab1 samples 


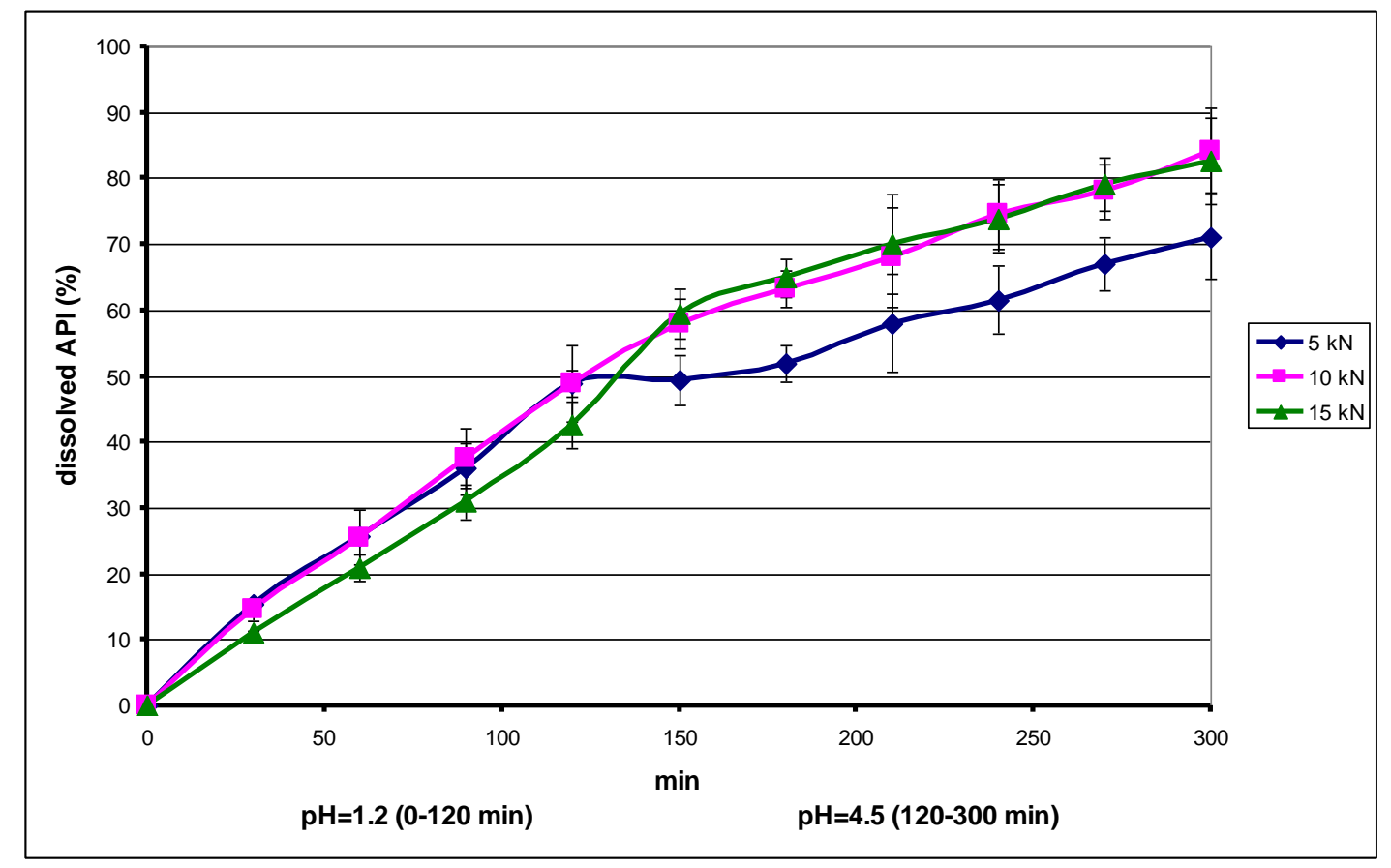

Figure 14. Dissolution curves for Ribotab2 samples

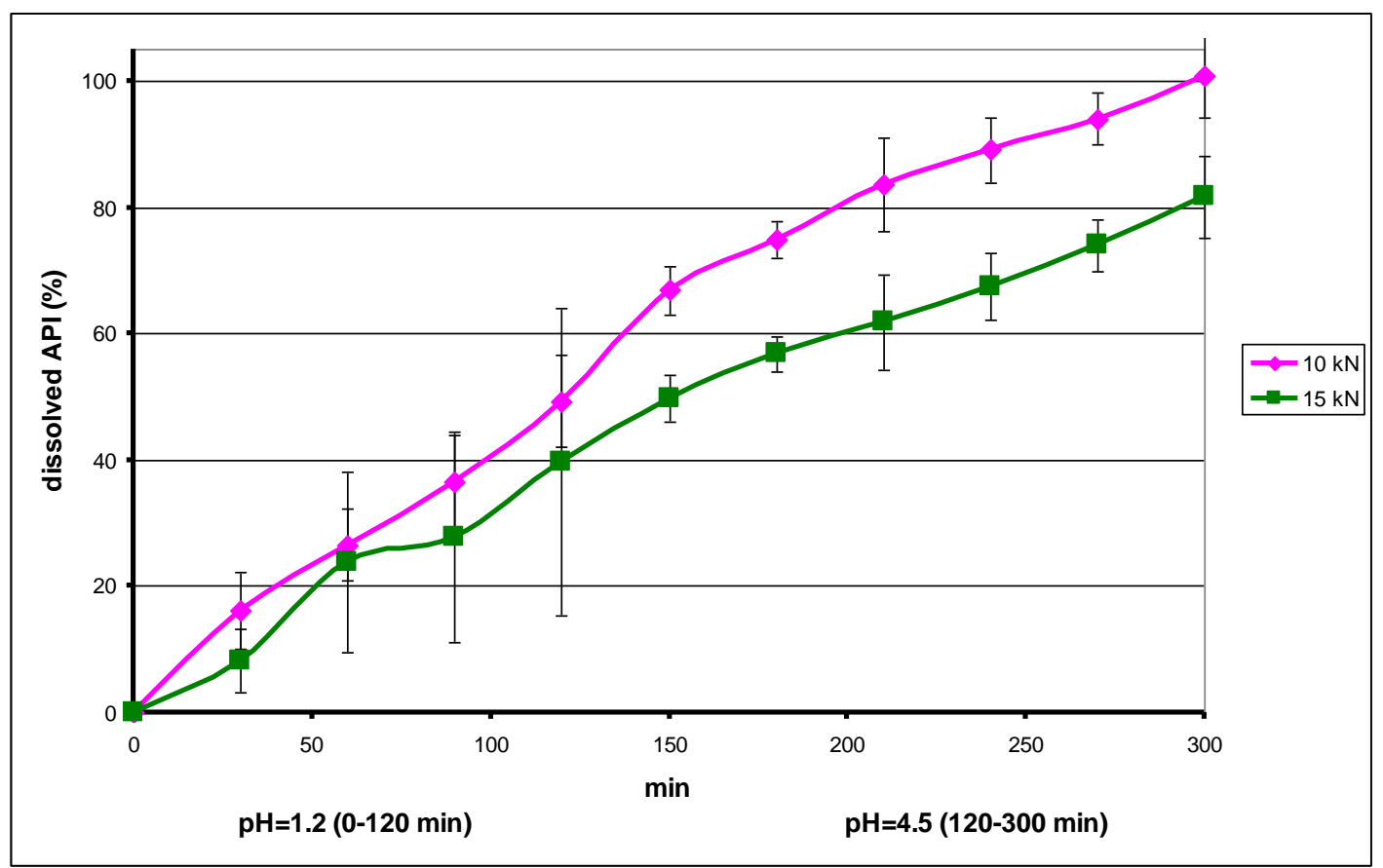

Figure 15. Dissolution curves for Ribotab3 samples 
Table 9. Fitting results of total dissolution profile

\begin{tabular}{|l|l|l|l|}
\hline Samples & $k$ & $n$ & $R^{2}$ \\
\hline Ribotab1-5kN & 0.9403 & 0.7525 & 0.9924 \\
Ribotab1-10kN & 1.0956 & 0.7149 & 0.9916 \\
Ribotab1-15kN & 1.2816 & 0.6483 & 0.9866 \\
\hline Ribotab2-5kN & 2.6359 & 0.5789 & 0.9860 \\
Ribotab2-10kN & 1.7948 & 0.6788 & 0.9920 \\
Ribotab2-15kN & 1.0872 & 0.7700 & 0.9777 \\
\hline Ribotab3-10kN & 1.2199 & 0.7808 & 0.9888 \\
Ribotab3-15kN & 0.7881 & 0.8148 & 0.9930 \\
\hline
\end{tabular}

The tablets produced at $5 \mathrm{kN}$ exhibited a low breaking hardness, and the dissolution process was not depicted here as the deviation was too high; these samples were omitted from the further experiments.

Table 10. Fitting results of each section of dissolution according to the Korsmeyer-Peppas model

\begin{tabular}{|l|l|l|l|l|l|l|}
\hline \multicolumn{1}{|c|}{ Samples } & \multicolumn{3}{|c|}{$0-120 \mathrm{~min}$} & \multicolumn{3}{c|}{$150-300 \mathrm{~min}$} \\
\cline { 2 - 7 } & $k$ & $n$ & $R^{2}$ & $k$ & $n$ & $R^{2}$ \\
\hline Ribotab1-5kN & 0.5277 & 0.8734 & 0.9986 & 1.8832 & 0.6262 & 0.9637 \\
Ribotab1-10kN & 0.3537 & 0.9690 & 0.9972 & 1.4535 & 0.6627 & 0.9705 \\
Ribotab1-15kN & 0.3052 & 0.9782 & 0.9982 & 1.2273 & 0.6547 & 0.9914 \\
\hline Ribotab2-5kN & 0.7368 & 0.8723 & 0.9971 & 2.9937 & 0.5542 & 0.9870 \\
Ribotab2-10kN & 0.6548 & 0.9001 & 0.9996 & 3.7644 & 0.5434 & 0.9944 \\
Ribotab2-15kN & 0.3487 & 1.0011 & 0.9991 & 5.5042 & 0.4751 & 0.9987 \\
\hline Ribotab3-10kN & 0.8557 & 0.8426 & 0.9971 & 3.7482 & 0.5771 & 0.9947 \\
Ribotab3-15kN & 0.4046 & 0.9562 & 0.9782 & 1.4330 & 0.7060 & 0.9929 \\
\hline
\end{tabular}


Table 11. Fitting results of each section of dissolution according to the linear model

\begin{tabular}{|l|l|l|l|l|l|l|}
\hline \multicolumn{1}{|c|}{ Samples } & \multicolumn{3}{|c|}{$0-120 \mathrm{~min}$} & \multicolumn{3}{c|}{$150-300 \mathrm{~min}$} \\
\cline { 2 - 7 } & $a$ & $b$ & $R^{2}$ & $a$ & $b$ & $R^{2}$ \\
\hline Ribotab1-5kN & 0.2845 & 1.0700 & 0.9956 & 0.1574 & 20.1773 & 0.9545 \\
Ribotab1-10kN & 0.3025 & 0.4147 & 0.9972 & 0.1562 & 17.1817 & 0.9685 \\
Ribotab1-15kN & 0.2736 & 0.2423 & 0.9982 & 0.1246 & 14.2783 & 0.9929 \\
\hline $\begin{array}{l}\text { Ribotab2-5kN } \\
\text { Ribotab2-10kN }\end{array}$ & 0.3946 & 1.5450 & 0.9943 & 0.1497 & 26.1577 & 0.9923 \\
Ribotab2-15kN & 0.4027 & 1.1415 & 0.9977 & 0.1742 & 31.7570 & 0.9961 \\
\hline $\begin{array}{l}\text { Ribotab3-10kN } \\
\text { Ribotab3-15kN }\end{array}$ & 0.3494 & 0.1023 & 0.9991 & 0.1543 & 36.9603 & 0.9964 \\
\hline
\end{tabular}

The results show, that both of the sections can be fitted by the linear model too. However the results with the Korsmeyer-Peppas model indicated that the matrix model fitting was better in most cases.

In earlier work, in which the swelling properties and swelling forces of different disintegrants were tested, it was concluded that in the case of disintegrating tablets the swelling curve can be fitted by the RRSBW equation (Eq. 2), and the swelling process can be characterized by the RRSBW model [53, 54].

In the present work, we studied the swelling properties of matrix tablets

Gelcarin GP 379, a swellable carrageenan, was used in the present experiment, and the tablets did not contain other excipients. The measured swelling force was therefore attributable only to the swelling of iota-carrageenan. The experiments were carried out at $\mathrm{pH} 1.2$ and $\mathrm{pH} 4.5$, both of which are to be found in the gastrointestinal tract. The results are shown in Table 12. 
Table 12. Swelling of iota-carrageenan tablets

Duration of experiments: $30 \mathrm{~min}$, temperature: $37 \pm 1{ }^{\circ} \mathrm{C}$

\begin{tabular}{|c|c|c|c|}
\hline $\begin{array}{c}\text { Compression force } \\
(\mathrm{kN})\end{array}$ & pH & $\begin{array}{l}\text { Swelling force } \\
\text { (N) }\end{array}$ & $\begin{array}{c}\text { Swelling time } \\
(\mathrm{min})\end{array}$ \\
\hline \multirow[t]{2}{*}{5} & 1.2 & $\begin{array}{c}3.006 \\
\text { SD }= \pm 0.098\end{array}$ & $\begin{array}{c}28.54 \\
\text { SD }= \pm 3.26\end{array}$ \\
\hline & 4.5 & $\begin{array}{c}2.952 \\
\text { SD }= \pm 0.388\end{array}$ & $\begin{array}{c}24.8 \\
\text { SD }= \pm 3.93\end{array}$ \\
\hline \multirow[t]{2}{*}{10} & 1.2 & $\begin{array}{c}2.106 \\
\text { SD }= \pm 0.885\end{array}$ & $\begin{array}{c}28.16 \\
\mathrm{SD}= \pm 2.05\end{array}$ \\
\hline & 4.5 & $\begin{array}{c}3.19 \\
\text { SD }= \pm 0.316\end{array}$ & $\begin{array}{c}27.58 \\
S D= \pm 2.89\end{array}$ \\
\hline \multirow[t]{2}{*}{15} & 1.2 & $\begin{array}{c}2.364 \\
\text { SD }= \pm 0.78\end{array}$ & $\begin{array}{c}28.52 \\
\text { SD }= \pm 2.88\end{array}$ \\
\hline & 4.5 & $\begin{array}{c}2.946 \\
\text { SD }= \pm 0.188\end{array}$ & $\begin{array}{c}27.12 \\
\text { SD }= \pm 2.66\end{array}$ \\
\hline
\end{tabular}

The measured swelling force exhibited values only in the range 2-3 $\mathrm{N}$, independently of $\mathrm{pH}$ and pressure, while the swelling time corresponding to the maximum swelling force was 25$28 \mathrm{~min}$

At the beginning of the process, fast swelling occurred, which was followed by slower swelling, but the force increased steadily. The curve could be fitted by the Korsmeyer-Peppas equation $\left(\mathrm{r}^{2}=0.9930\right)$ (Fig. 16.) from $0 \mathrm{~min}$ up to approximately $25-28 \mathrm{~min}$. In the period of formation of the gel barrier, there is strong physicochemical bonding between the polymer particles. After this period, further water molecules penetrate into the matrix and rearrangement of the bonding between the polymers occurs. Our experiments demonstrated that from this point the curve is basically linear (Fig. 16.). 


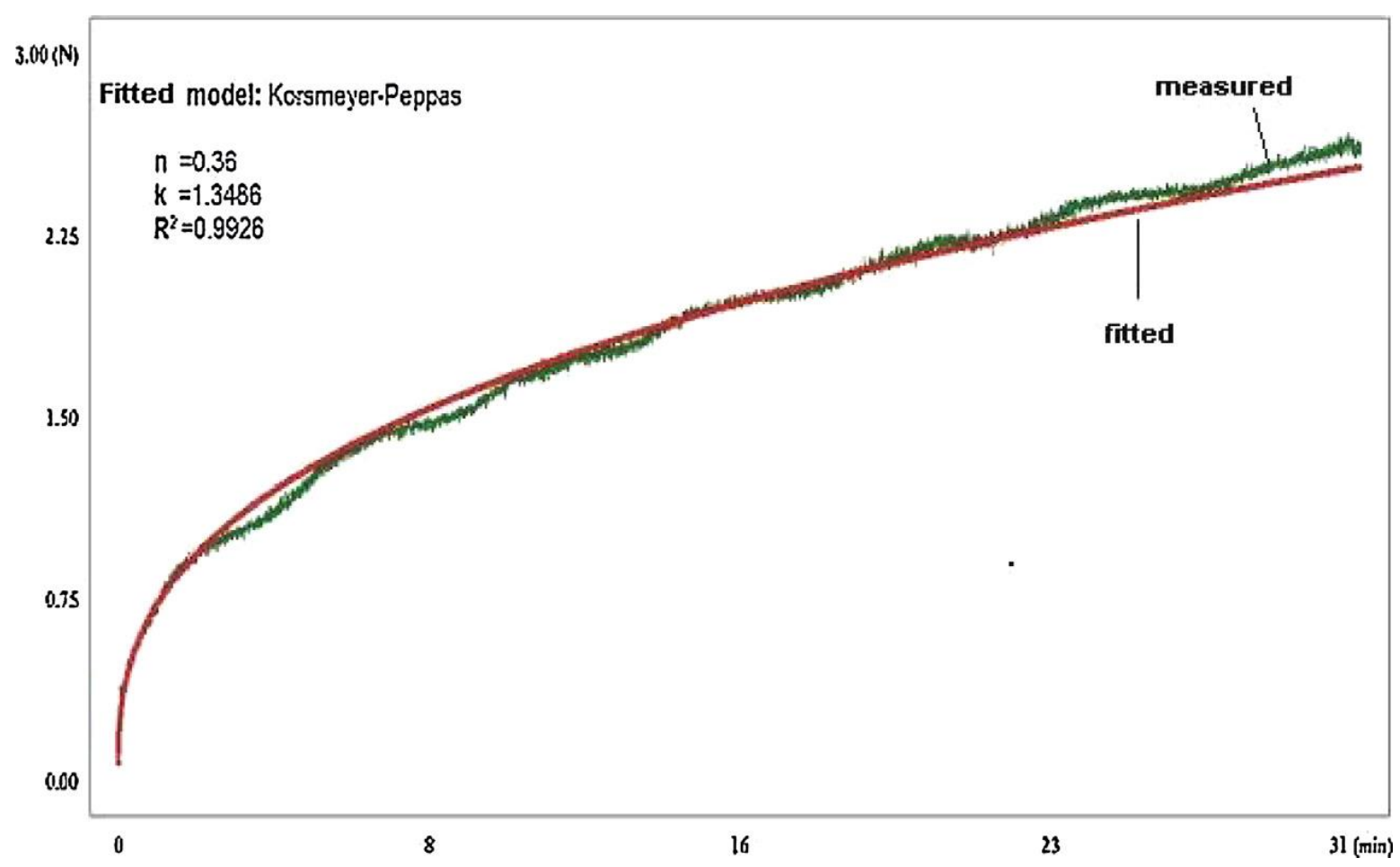

Figure 16. Swelling curve of iota-carrageenan comprimate (compression force: $15 \mathrm{kN}$ ).

The results demonstrated that the shapes of the swelling curves were independent of $\mathrm{pH}$ and the compression force. It may therefore be supposed that iota-carrageenan matrix tablets will behave similarly in the gastrointestinal tract as concerns the process of dissolution from sustained-release tablets.

\subsubsection{Conclusions}

It was concluded that the lactose content influences the physical parameters, the degree of dissolution and the profile of dissolution. When the proportion of lactose was smaller, the elasticity of the matrix was higher, which resulted in tablets with weak mechanical properties. Furthermore, the macromolecular particles could swell very well in the dissolution medium. The dissolution profiles could be fitted best with the Korsmeyer-Peppas model, but thanks to the lactose content the dissolution sometimes occurred in two phases.

Application of a swelling force meter revealed the changes in the swelling force in matrix tablets. Two sections were observed in the swelling process: in the first, the degree of swelling and the swelling force were higher because of the strong bonds between the macromolecules, and this section could be fitted with the Korsmeyer-Peppas equation. In the second section, 
the bonds became weaker and the rate of increase of the swelling force decreased. This test characterized very well the swelling process of the matrix system.

\section{FINAL CONCLUSIONS, NOVELTY, PRACTICAL USEFULNESS}

As described in the Introduction the aim was to develop modified release preparations containing riboflavin by different technological methods. Riboflavin was particularly suitable because it is absorbed to only a limited extent in the duodenum and jejunum as its passage through this region is rapid. The bioavailability of riboflavin may be increased by administration of a gastroretentive or modified release dosage form.

The important novelty and practical usefulness of this work may be summarized as follows:

- A new solid dosage form was developed through the layering of aqueous sodium riboflavin 5'-phosphate solution onto the surface of microcrystalline pellets (Cellet 300 as core material), which were then filled into capsules.

- The coating of the capsules was investigated and the influence of the thickness of the coating layer on the dissolution of sodium riboflavin 5'-phosphate was tested. The optimum film thickness was predicted with regard to the modified release of sodium riboflavin 5'-phosphate.

- Monolithic matrix tablets containing sodium riboflavin 5'-phosphate were prepared by wet granulation according to a $3^{2}$ full factorial design. A suitable MCC/lactose ratio and the best compression force were determined as concern an appropriate dissolution profile.

- A new swelling force meter was developed for measurement of the swelling force in matrix tablets and characterization of the profile of the swelling curve. The swelling force meter was linked to a PC by an RS232 cable and the measured data 
were evaluated with self-developed software. The monitor displayed the swelling force vs. time curve with the important parameters, which could be fitted with an Analysis menu. This equipment can be generally applied for matrix systems.

The results and observations of the present study provide useful information for industrial technologists. 


\section{REFERENCES}

[1] Pagliaro A. M., Pagliaro L. A.:Pharmacologic Aspects of Nursing, The C.V, Mostby Company, St. Louis, 1986;1521

[2] Gilman A. G., Rall T. W., Nies A. S., Taylor P.:Goodman and Gilman's The Pharmacological Basis of Therapeutics, Pergamon Press, New York, 1990;1534-1535

[3] Kalant,H., Roschlau W.H.E., Sellers, E.M.: Principles of Medical Pharmacology, Department of Pharmacology, University of Toronto, 1985;581

[4] Kagan L., Lapidot N., Afargan M., Kirmayer D., Moor E., Mardor Y., Friedman M., Hoffmann A.: Gastroretentive Accordion Pill: enhancement of riboflavin bioavailability in humans. J. Cont. Rel. 2006;113:208-215

[5] Herting, M.G., Kleinebudde, P.:Roll compaction/dry granulation: Effect of raw material particle size on granule and tablet properties. International Journal of Pharmaceutics, 2007;338(1-2):110-118

[6] Wade, J.B., Martin, G.P., Long, D.F.: Feasibility assessment for a novel reverse-phase wet granulation process: The effect of liquid saturation and binder liquid viscosity International Journal of Pharmaceutics, 2014;475(1-2):450-461

[7] Hansuld, E.M., Briens, L.: A review of monitoring methods for pharmaceutical wet granulation. International Journal of Pharmaceutics, 2014;472(1-2):192-201

[8] Vemavarapu, C., Surapaneni, M., Hussain, M., Badawy, S.: Role of drug substance material properties in the processibility and performance of a wet granulated product. International Journal of Pharmaceutics, 2009;374(1-2):96-105

[9] Giry, K., Genty, M., Viana, M., Wuthrich, P., Chulia, D.: Multiphase versus Single Pot Granulation Process: Influence of Process and Granulation Parameters on Granules Properties. Drug Development and Industrial Pharmacy, 2006;32:509-530

[10] Parikh D.M.: Handbook of Pharmaceutical Granulation Technology, Marcel Dekker, Inc., New York, 2009

[11] Ghebre-Selassie, I.: Pharmaceutical Pelletization Technology, Marcel Dekker Inc., New York, 1989 
[12] Hibare, S., Acharya, K.: Effect of binder to solid ratio on mechanical properties of granules processed using reactive and non-reactive binder. Powder Technology, 2012;229:137-147

[13] Kumar, A., Gernaey, K.V., De Beer, T., Nopens, I.: Model-based analysis of high shear wet granulation from batch to continuous processes in pharmaceutical production - A critical review. European Journal of Pharmaceutics and Biopharmaceutics, 2013;85(3):814-832

[14] Cavinato, M., Andreato, E., Bresciani, M., Pignatone, I., Bellazzi, G., Franceschinis, G., Realdon, N., Canu, P., Santomaso. A.C.: Combining formulation and process aspects for optimizing the high-shear wet granulation of common drugs. International Journal of Pharmaceutics, 2011;416(1):229-241

[15] Cavinato, M., Bresciani, M., Machin, M., Belazzi, G., Canu, P., Santomaso, A. C.: Formulation design for optimal high-shear wet granulation using on-line torque measurements. International Journal of Pharmaceutics 2010; 387:48-55.

[16] Frenning G. Modelling drug release from inert matrix systems: From movingboundary to continuous-field descriptions. International Journal of Pharmaceutics 2011;418:88-99.

[17] Sandra U. Schilling, James W. McGinity: Novel application of hot-melt extrusion for the preparation of monolithic matrices containing enteric-coated particles. International Journal of Pharmaceutics, 2010;400(1-2):24-31

[18] Lyons, J.G., Blackie, P., Higginbotham, C.L.: The significance of variation in extrusion speeds and temperatures on a PEO/PCL blend based matrix for oral drug delivery. International Journal of Pharmaceutics, 2008;351(1-2):201-208

[19] Pradhan, R., Kim, Y-I., Chang, S.W., Kim, J.O.: Preparation and evaluation of oncedaily sustained-release coated tablets of tolterodine-1- tartrate. International Journal of Pharmaceutics, 2014;460(1-2):205-211

[20] Bonferoni M.C. et al. On the employment of $\lambda$ carrageenan in a matrix system. III. Optimization of a $\lambda$ carrageenan-HPMC hydrophilic matrix. Journal of Controlled Release, 1998;51:231-239

[21] Gupta V.K. et al. Controlled -release tablets from carrageenans: effect of formulation, storage and dissolution factors. European Journal of Pharmaceutics and Biopharmaceutics, 2001;51:241-242. 
[22] Nerurkar J. et al. Controlled-release matrix tablets of ibuprofen using cellulose ethers and carrageenans: effect of formulation factors on dissolution rates. European Journal of Pharmaceutics and Biopharmaceutics, 2005;61:56-68.

[23] Dorożyński P. et al. Gastroretentive drug delivery systems with L-dopa based oncarrageenans and hydroxypropylmethylcellulose. International Journal of Pharmaceutics, 2011;404:169-170.

[24] FMC Corporation Technical Literature, 2013

[25] Pavli M.et al. Matrix tablets based on carrageenans with dual controlled release of doxazosin mesylate. International Journal of Pharmaceutics, 2010;400:15-16.

[26] Kranz H.et al. Drug release from MCC- and carrageenan-based pellets: Experiment and theory. European Journal of Pharmaceutics and Biopharmaceutics, 2009;73:302303.

[27] Liu, J., Zhan, X., Wan, J., Wang, Y., Wang, C.: Review for carrageenan-based pharmaceutical biomaterials: Favourable physical features versus adverse biological effects. Carbohydrate Polymers, 2015;121:Pages 27-36

[28] Li, L., Ni, R., Shao, Y., Mao, S.: Carrageenan and its applications in drug delivery. Carbohydrate Polymers, 2014;103:1-11

[29] Aksornkoae, N.: Controlled drug release from compressed matrices preparedwith carrageenans. University of Tennessee, 2002 (Dissertation).

[30] Felician, W.A., Ghaly, E.S.: Development and evaluation of nifedipine controlledrelease tablets prepared using mucoadhesive swellable polymer. Pharm. Dev.Technol. 2011;16:536-541.

[31] Picker, K.M.: Matrix tablets of carrageenans. II. Release behaviour and effect ofadded cations. Drug Dev. Ind. Pharm, 1999;25:339-346.

[32] Teller, R.S., Rastogi, R., Johnson, J.T., Blair, J.M., Hitchcock, W.R., Kiser, P.F.: Intravaginal flux controlled pum for sustained release of macromolecules. Pharm.Res., 2014;31:2344-2353.

[33] Westman, L., T. Lindström, T.:Swelling and mechanical properties of cellulosehydrogels. III. Temperature effects on the swelling and compliance levels stud-ied by dilatometry and1H NMR spectroscopy. J. Appl. Polym. Sci., 1981;26:2545-2559.

[34] Just S., Toschkoff G., Funke A., Djuric D., Scharrer G., Khinast J., Knop K., Kleinebudde P.: Optimatization of the inter-tablat coating uniformity for an active 
coating process at lab and pilot scale. International Journal of Pharmaceutics, $2013 ; 457: 1-8$

[35] Joshi, S., Petereit, H.-U.: Film coatings for taste masking and moisture protection. International Journal of Pharmaceutics,2013;457:395- 406

[36] Porter, S.C., Felton. L.A.: Techniques to assess film coatings and evaluate film-coated products. Drug Development and Industrial Pharmacy, 2010;36(2):128-142

[37] Just, S., Toschkoff, G., Funkec, A., Djuric, D., Scharrer, G., Khinast, J., Knop, K., Kleinebudde, P.: Optimization of the inter-tablet coating uniformity for an active coating process at lab and pilot scale. International Journal of Pharmaceutics, $2013 ; 457: 1-8$

[38] Cole, G., Hogen, J.: Pharmaceutical coating technology, Taylor \& Francis Ltd., London, 1995.

[39] Siepmann, J., Siepmann, F.: Stability of aqueous polymeric controlled release film coatings. International Journal of Pharmaceutics, 2013;457(2):437-445

[40] Guo H.X., Heinämäki J., Yliruusi J.: Amylopectin as a subcoating material improves the acidic resistance of enteric-coated pellets containing a freely soluble drug. International Journal of Pharmaceutics, 2002;235:79-86

[41] Nollenberger, K., Albers, J.: Poly(meth)acrylate-based coatings. International Journal of Pharmaceutics, 2013;457(2):461-469

[42] El-Malah, Y., Nazzal, S.: Novel use of Eudragit ${ }^{\circledR}$ NE 30D/Eudragit® L 30D-55 blends as functional coating materials in time-delayed drug release applications. International Journal of Pharmaceutics, 2008;357(1-2):219-227

[43] Lunter, D.J., Daniels, R.: New film forming emulsions containing Eudragit ${ }^{\circledR}$ NE and/or RS 30D for sustained dermal delivery of nonivamide. European Journal of Pharmaceutics and Biopharmaceutics, 2012;82(2):291-298

[44] Krajacic, A., Tucker, I. G.: Matrix formation in sustained release tablets: possible mechanism of dose dumping. International Journal of Pharmaceutics, 2003;251,(12):67-78

[45] Jusko, W.J., Levy, G.: Absorption, metabolism, and excretion of riboflavin-5'phosphate in man. J. Pharm. Sci., 1967;56(1):58-62

[46] Münzel, K.: Die “Zerfallsprüfung” einzeldosierter oraler Arzneiformen mit verlängerter Wirkung in vitro. Arch. Pharm., 1960;293(65):766-785 
[47] Costa, P. and Lobo, J.M.S: Modeling and comparison of dissolution profiles. Eur. J. Pharm. Sci., 2001;13:123-133

[48] Hamedelniel I. E., Bajdik J., Sovány T., Kása P. Jr., Pintye-Hódi K.: Effects of the wetting liquid and ethylcellulose on the properties of atenolol-containing pellets, JDDST, 2011;21:195-200

[49] Langenbucher, F.: Parametric representation of Dissolution-Rate Curves by the RRSBW Distribution. Pharm Ind., 1976;38:472-477

[50] Xie, M. and Jiang, R.: Weibull Models. John Wiley \& Sons, Inc. 200:499-100

[51] Grossman, S.I. and Derrick, W.R.: Advanced engineering mathematics. New York, NY: Harper Collins Publishers, Inc. 1988. p.1089

[52] European Pharmacopoeia, 4th ed. Strasbourg Cedex, France: Council of Europe; 2001.

[53] Kelemen, A.: Dynamic force measurement in preformulation of solid dosageforms, University of Szeged, 2013 (Dissertation).

[54] Kelemen, A., Szöllösi, A., Zsótér, A., Pintye-Hódi, K., Török, Cs., Erős, I.: Measurement of the swelling force of some sodium starch glycolate products with newsoftware, Hung. J. Ind. Chem., 2002;30:73-76.

[55] Chitu TM, Oulahna D, Hemati M. Wet granulation in laboratory scale high shear mixers: effect of binder properties. Powder Technol., 2011;206:25-33

[56] Levin M. Wet granulation: end-point determination and scale-up. Available from: http://www.mcc-online.com/granulation.htm [last accessed 14 April 2014].

[57] Gohel MC, Jogani PD, Bariya SE.: Development of agglomerated directly compressible diluent consisting of brittle and ductile materials. Pharm Dev Technol., 2003;8:143-151 


\section{ACKNOWLEDGEMENTS}

I am very grateful to my supervisor

Professor Dr. Habil. Klára Pintye-Hódi Ph.D., D.Sc.

for her support. I greatly appreciate her continuous help during the preparation of my thesis and providing the excellent facilities for my $\mathrm{Ph}$. D. studies.

I would like to thank

Professor Dr. Habil. Piroska Szabó-Révész Ph.D, D.Sc.

Head of the Ph. D. programme Pharmaceutical Technology and present Head of the

Department of Pharmaceutical Technology for providing me with the possibility to complete my work under her guidance.

I would like to thank

\section{Professor Dr. Habil. István Erős Ph.D, D.Sc.}

Former Head of the Department of Pharmaceutical Technology for providing me with the possibility to complete my work under his guidance.

I express my kindest thanks all my co-authors for their collaboration in this work. Help from all members in the Department of Pharmaceutical Technology, and some other departments will be greatly appreciated. 


\section{APPENDIX}

\section{PUBLICATIONS RELATED TO THE THESIS}


